Waste/Rock Interactions Technology

Program

\title{
Status Report on LWR Spent Fuel IAEA Leach Tests
}

Y. B. Katayama

D. J. Bradley

C. O. Harvey

March 1980

Prepared for the

Office of Nuclear Waste Isolation

under its Contract with the

U.S. Department of Energy

Pacific Northwest Laboratory

Operated for the U.S. Department of Energy

by Battelle Memorial Institute 


\title{
NOTICE
}

This report was prepared as an account of work sponsored by the United States Government. Neither the United States nor the Department of Energy, nor any of their employees, nor any of their contractors, subcontractors, or their employees, makes any warranty, express or implied, or assumes any legal liability or responsibility for the accuracy, completeness or usefulness of any information, apparatus, product or process disclosed, or represents that its use would not infringe privately owned rights.

The views, opinions and conclusions contained in this report are those of the contractor and do not necessarily represent those of the United States Government or the United States Department of Energy.

\section{PACIFIC NORTHWEST LABORATORY operated by \\ BATTELLE \\ for the \\ UNITED STATES DEPARTMENT OF ENERGY \\ Under Contract DE-AC06-76RLO 1830}

\author{
Printed in the United States of America \\ Available from \\ National Technical Information Service \\ United States Department of Commerce \\ 5285 Port Royal Road \\ Springfield, Virginia 22151
}

Price: Printed Copy $\$$ $\because$ Microfiche $\$ 3.00$

$\begin{array}{cr}\text { •Pages } & \begin{array}{c}\text { NTIS } \\ \text { Selling Price }\end{array} \\ 001-025 & \$ 4.00 \\ 026-050 & \$ 4.50 \\ 051-075 & \$ 5.25 \\ 076-100 & \$ 6.00 \\ 101-125 & \$ 6.50 \\ 126-150 & \$ 7.25 \\ 151-175 & \$ 8.00 \\ 176-200 & \$ 9.00 \\ 201-225 & \$ 9.25 \\ 226-250 & \$ 9.50 \\ 251-275 & \$ 10.75 \\ 276-300 & \$ 11.00\end{array}$


PNL -3173

Waste/Rock Interactions Technology Program

STATUS REPORT ON LWR SPENT FUEL

IAEA LEACH TESTS

Y. B. Katayama

D. J. Bradley

C. 0. Harvey

March 1980

Prepared for the

Office of Nuclear Waste Isolation

U.S. Department of Energy

under Contract DE-AC06-76RLO 1830

Pacific Northwest Laboratory

Richland, Washington 99352 



\section{SUMMARY}

Spent light-water-reactor (LWR) fuel with an average burnup of 28,000 MWd/ MTU was leach-tested at $25^{\circ} \mathrm{C}$ using a modified version of the International Atomic Energy Agency (IAEA) procedure. Leach rates were determined from tests conducted in five different solutions: deionized water, sodium chloride $(\mathrm{NaCl})$, sodium bicarbonate $\left(\mathrm{NaHCO}_{3}\right)$, calcium chloride $\left(\mathrm{CaCl}_{2}\right)$ and Waste Isolation Pilot Plant (WIPP) "B" brine solutions. Elemental leach rates are reported based on the release of ${ }^{90} \mathrm{Sr}+{ }^{90} \mathrm{Y},{ }^{106} \mathrm{Ru},{ }^{137} \mathrm{Cs},{ }^{144} \mathrm{Ce}$, ${ }^{154} \mathrm{Eu},{ }^{239+240} \mathrm{Pu},{ }^{244} \mathrm{Cm}$ and total uranium.

After 467 days of cumulative leaching, the elemental leach rates are highest in deionized water. The elemental leach rates in the different solutions generally decreased from deionized water to the $0.03 \mathrm{M} \mathrm{NaCl}$ solution to the WIPP "B" brine solution to the $0.03 \mathrm{M} \mathrm{NaHCO}_{3}$ solution and was a factor of 20 lower in $0.015 \mathrm{M} \mathrm{CaCl}_{2}$ solution than in deionized water.

The leach rates of spent fuel and borosilicate waste-glass were also compared. In sodium bicarbonate solution, the leach rates of the two waste forms were nearly equal, but the glass was increasingly more resistant than spent fuel in calcium chloride solution, followed by sodium chloride solution, WIPP "B" brine solution and deionized water. In deionized water the glass, based on the elemental release of plutonium and curium, was 50 to 400 times more leach resistant than spent fuel. 
, 


\section{ACKNOWLEDGMENT}

This research was supported by the Waste/Rock Interactions Technology Program conducted by Pacific Northwest Laboratory. The Waste/Rock Interactions Technology program is sponsored by the Office of Nuclear Waste Isolation, which is managed by Battelle Memorial Institute for the U.S. Department of Energy under contract DE-AC06-76RLO 1830.

The authors are grateful to C. E. Bigelow, H. J. Cartmell and J. C. Nelson for their assistance in performing the experiments. 

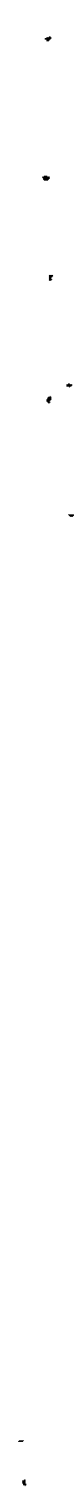

: 
CONTENTS

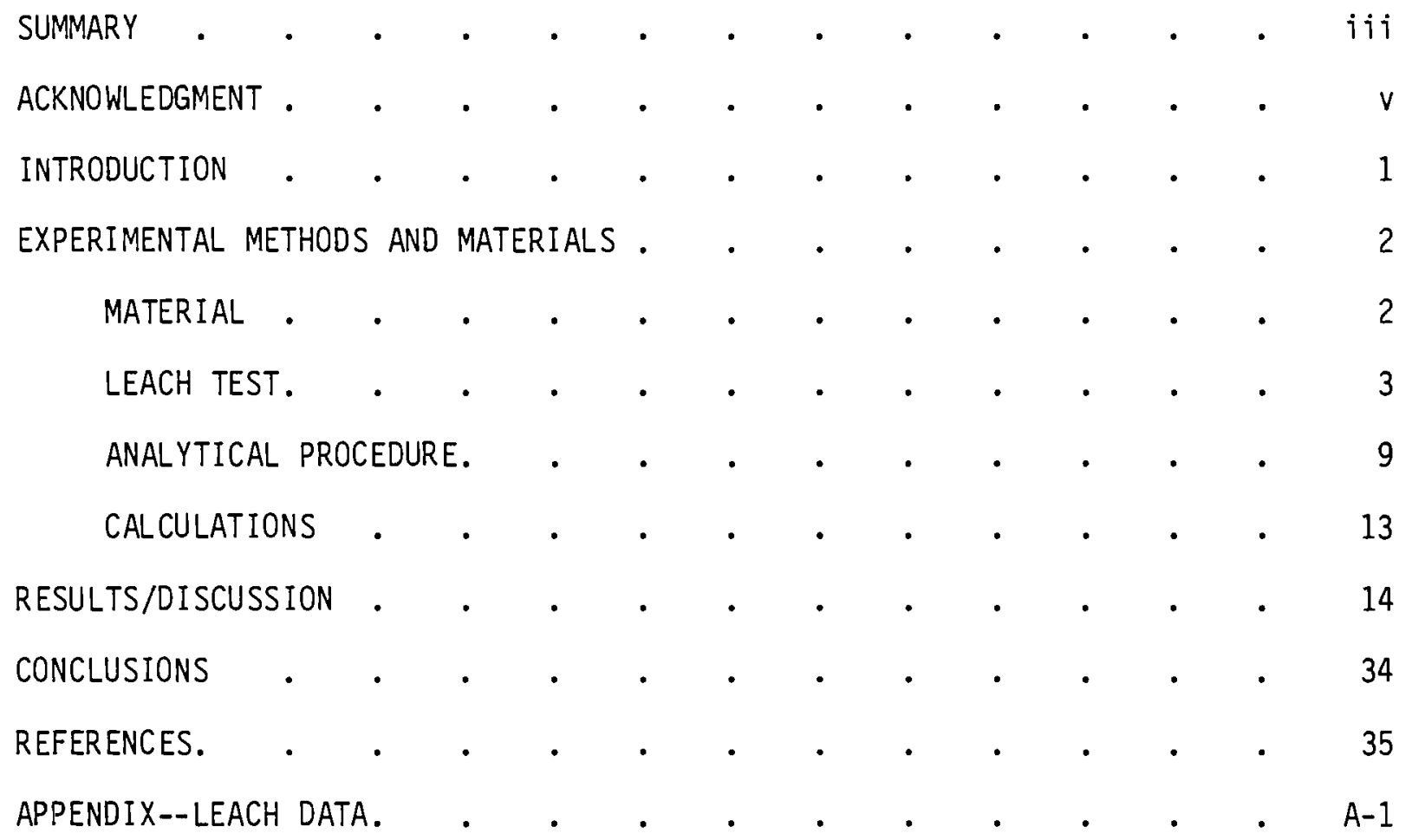

vii 


\section{FIGURES}

1 Appearance of Spent Fuel with a Burnup of $28,000 \mathrm{MWd} / \mathrm{MTU}$ - $\quad 4$

2 Fragment of HB Robinson II Fuel, 28,000 MWd/MTU, Showing Microprobe Step-Scanning Path From point A to point B (Edge to Center) . . 5

3 Microprobe Measured X-Ray Intensities for Plutonium, Technetium and Barium.

4 Microprobe Measured X-Ray Intensities for Cesium, Zirconium and Iodine.

5 Microprobe Measured X-Ray Intensities for Ruthenium, Tellurium and Cerium.

6 Spent LWR Fuel Fragments Photographed Through Hot-Cel1 Periscope.

7 IAEA Leach-Test Container. . . . . . . . . . . 12

8 Leach Rate of 28,000 MWd/MTU Spent Fuel at $25^{\circ} \mathrm{C}$ Based on Release of Uranium . . . . . . . . . . . 15

9 Leach Rate of 28,000 MWd/MTU Spent Fuel at $25^{\circ} \mathrm{C}$ Based on Release of $137 \mathrm{CS}$

10 Leach Rate of $28,000 \mathrm{MWd} / \mathrm{MTU}$ Spent Fuel at $25^{\circ} \mathrm{C}$ Based on

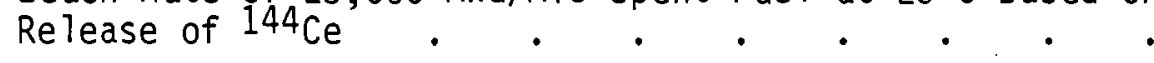

11 Leach Rate of $28,000 \mathrm{MWd} / \mathrm{MTU}$ Spent Fuel at $25^{\circ} \mathrm{C}$ Based on Release of $239+240 \mathrm{Pu}$

12 Leach Rate of $28,000 \mathrm{MWd} / \mathrm{MTU}$ Spent Fuel at $25^{\circ} \mathrm{C}$ Based on Release of $244 \mathrm{Cm}$

13 Leach Rate of $28,000 \mathrm{MWd} / \mathrm{MTU}$ Spent Fuel at $25^{\circ} \mathrm{C}$ Based on Release of $90 \mathrm{Sr}+90 \mathrm{Y} . . .1$. .

14 Leach Rate of $28,000 \mathrm{MWd} / \mathrm{MTU}$ Spent Fuel at $25^{\circ} \mathrm{C}$ Based on Release of $154 \mathrm{E}$

15 Leach Rate of $28,000 \mathrm{MWd} / \mathrm{MTU}$ Spent Fuel at $25^{\circ} \mathrm{C}$ Based on Release of $125 \mathrm{Sb}$

16 Leach Rate of $28,000 \mathrm{MWd} / \mathrm{MTU}$ Spent Fuel at $25^{\circ} \mathrm{C}$ Based on

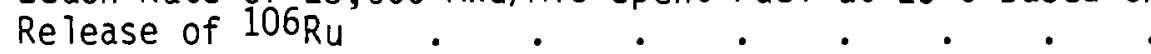


17 Leach Rate of 28,000 MWd/MTU Spent Fuel in Deionized Water

at $25^{\circ} \mathrm{C}$ Based on Selected Elements . . . . . .

18 Leach Rate of $28,000 \mathrm{MWd} / \mathrm{MTU}$ Spent Fuel in $0.03 \mathrm{M} \mathrm{NaCl}$

at $25^{\circ} \mathrm{C}$ Based on Selected Elements . . . . . . . . . 26

19 Leach Rate of 28,000 MWd/MTU Spent Fuel in WIPP "B" Saturated Brine Solution at $25^{\circ} \mathrm{C}$ Based on Selected Elements . . . . 27

20 Leach Rate of $28,000 \mathrm{MWd} / \mathrm{MTU}$ Spent Fuel in $0.03 \mathrm{M} \mathrm{NaHCO}_{3}$ at $25^{\circ} \mathrm{C}$ Based on Selected Elements. . . . . . . 28

21 Leach Rate of $28,000 \mathrm{MWd} / \mathrm{MTU}$ Spent Fue 1 in $0.015 \mathrm{M} \mathrm{CaCl}_{2}$ Solution at $25^{\circ} \mathrm{C}$ Based on Selected Elements . . . . . 30 


\section{$\underline{T A B L E S}$}

1 Particle Size Distribution of 28,000 MWd/MTU Spent Fuel. . . 2

2 IAEA Leach-Test Schedule . . . . . . . . . 10

3 Chemical and Ionic Composition of Salt Brine . . . . . 11

4 Results of Effects of Solution Type of Each Element . . $\quad 24$

5 Relative Leachability of Spent fuel in Various Leach Solutions Based on Average Trend of Leach Curves After 467 Days of Cumulative Leaching. . . . . . . . . . 31

6 Results of Comparing Incremental Leach Rates of Elements for

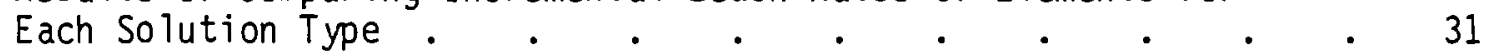

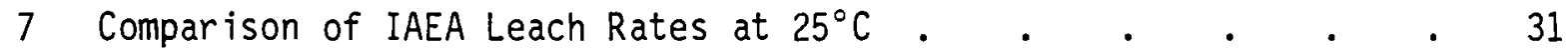

8 Comparison of IAEA Leach Rates of Paige-Test Leach Rates

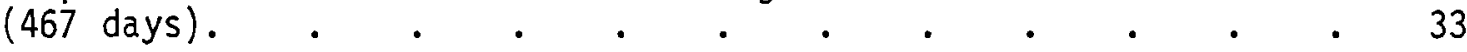




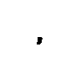




\section{INTRODUCTION}

In 1977, the Pacific Northwest Laboratory (PNL), operated by Battelle Memorial Institute for the Department of Energy, started a task to study spentfuel leaching as a part of the Waste Isolation Safety Assessment Program (WISAP). Radionuclide release information from spent fuel, a candidate waste form for geologic disposal, is needed to evaluate the safety of repository storage of spent fuels. These data are used both in release-consequence modeling and as source terms for radionuclide migration experiments.

There are many types of leach tests being used to evaluate solidified waste forms (Mendel 1973). At PNL spent fuels have been leach-tested by three different procedures: Paige tests, static leach tests, and the IAEA procedure. Paige leach tests on spent LWR fuels have been previously reported (Katayama 1979), and results from static leach tests of spent fuel will be reported as radiochemical analyses of stored and ongoing leachant samples are completed. The static leach tests are designed to give detailed data on spent fuel solubilities at $25^{\circ}$ and $75^{\circ} \mathrm{C}$. This status report presents results from leachtesting LWR spent fuel with an average burnup of 28,000 MWd/MTU using a modified version of the IAEA procedure at $25^{\circ} \mathrm{C}$. Release rates are discussed as a function of the duration of the leach tests and of the solution type.

This and future status reports on spent-fuel leaching will be reported as a part of the Waste/Rock Interactions Technology Program (WRIT). The WRIT Program, started in FY-1980 at PNL, includes Tasks 2 and 4 of WISAP. 


\section{EXPERIMENTAL METHODS AND MATERIALS}

MATERIAL

The spent fuel used in this study originated from a fuel bundle discharged on June 6, 1974 from the HB Robinson II Reactor and has an average burnup of 28,000 MWd/MTU. The fuel was removed from the fuel rods at the BattelleColumbus Hot Laboratory and was received at PNL as a mixture of unclad fuel fragments. A sample of this material was submitted to the Hanford Engineering Development Laboratory for radiochemical analysis. These analytical values for the radionuclides were used as the initial concentration in the leach rate calculations.

A randomly selected batch of the as-received fuel fragments was screened to provide a particle size distribution (see Table 1). Samples for the leach tests were taken from particle fractions retained on screens \#5 and \#10 (greater than 2-mm particles).

TABLE 1. Particle Size Distribution of $28,000 \mathrm{MWd} / \mathrm{MTU}$ Spent Fuel

\begin{tabular}{|c|c|c|c|}
\hline $\begin{array}{l}\text { Sieve } \\
\text { Number }\end{array}$ & $\begin{array}{c}\text { Sieve Opening, } \\
\text { mm }\end{array}$ & $\begin{array}{l}\text { Weight, } \\
\end{array}$ & Fraction Retained \\
\hline 3 & 6.73 & 0 & 0 \\
\hline 4 & 4.73 & 192.883 & $1.007 \times 10^{-1}$ \\
\hline 5 & 4.00 & 634.765 & $3.331 \times 10^{-1}$ \\
\hline 10 & 2.00 & 1031.170 & $5.384 \times 10^{-1}$ \\
\hline 20 & 0.841 & 35.205 & $1.838 \times 10^{-2}$ \\
\hline 40 & 0.420 & 11.242 & $5.869 \times 10^{-3}$ \\
\hline 60 & 0.250 & 4.979 & $2.599 \times 10^{-3}$ \\
\hline 80 & 0.177 & 1.424 & $7.434 \times 10^{-4}$ \\
\hline 100 & 0.149 & 1.042 & $5.440 \times 10^{-4}$ \\
\hline 140 & 0.105 & 1.204 & $6.286 \times 10^{-4}$ \\
\hline 200 & 0.074 & 0.769 & $4.015 \times 10^{-4}$ \\
\hline 200 & 0.074 & 0.737 & $3.848 \times 10^{-4}$ \\
\hline
\end{tabular}


Samples of the as-received spent fuel were also mounted, polished and examined by metallography for microstructural characterization of the fuel. Metallographic examination of spent-fuel fragments from the HB Robinson II reactor showed the presence of closed porosity (see Figure 1). Cathodic etching of the surface showed equiaxed grains with little change in size from the center of the pellet to the outer edge (magnified portion in Figure 1 is typical of entire sample).

Chemical-concentration profiles for selected radionuclides were recorded as fluorescence $X$-ray intensities on a shielded electron-beam microprobe X-ray analyzer. Various fuel fragments, typical of the samples in our leach tests, are now being analyzed. The data presented here are for a fragment of fuel with a burnup of $28,000 \mathrm{MWd} / \mathrm{MTU}$. Figure 2 shows a segment of a transverse section. The microprobe was programmed to step-scan the sample from point $A$ at the outside diameter of the pellet to point $B$ near the center of the pellet. Concentration profiles for elements measured by step scanning are expressed as $X$-ray intensities in Figures 3,4 and 5 .

Plutonium, cesium, ruthenium, technetium, barium, zirconium and cerium showed enrichment near the outer edge (point A). Iodine and tellurium showed no indication of enrichment at the outer edge. Plutonium showed the highest gradient from edge to center (point $A$ to point $B$ ), with a $47 \%$ reduction in $X$-ray intensity 300 um inward from point $A$ and an additional $28 \%$ drop over the next $3600 \mu \mathrm{m}$ to point $B$.

\section{LEACH TEST}

The modified IAEA leach test involves the immersion of a spent-fuel sample in a solution according to a fixed ratio of $1: 10\left(\mathrm{~cm}^{2} / \mathrm{cm}^{3}\right)$ of exposed surface area of sample to volume of solution. The solution is then left in contact with the sample for progressively longer time intervals. The solution is changed after each time interval. Between each sampling period the system is not disturbed via stirring or shaking. Although the leach container is left static during the leaching interval, the thermal power of the spent fuel of about $5 \mathrm{cal} \mathrm{h}^{-1} \mathrm{~g}^{-1}$ is a source of convective (thermal) agitation at the 

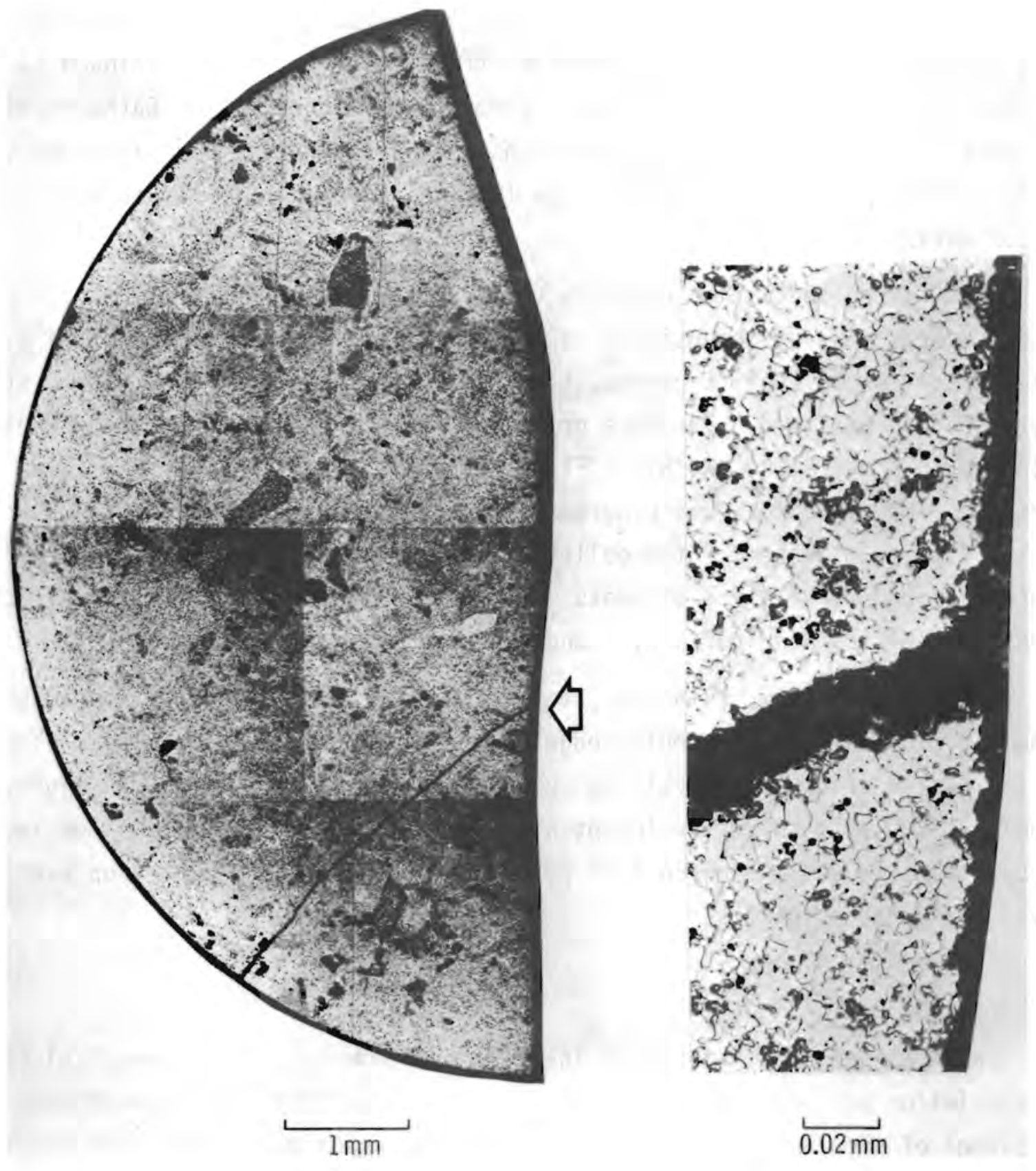

FIGURE 1. Appearance of Spent Fuel with a Burnup of 28,000 MWd/MTU 


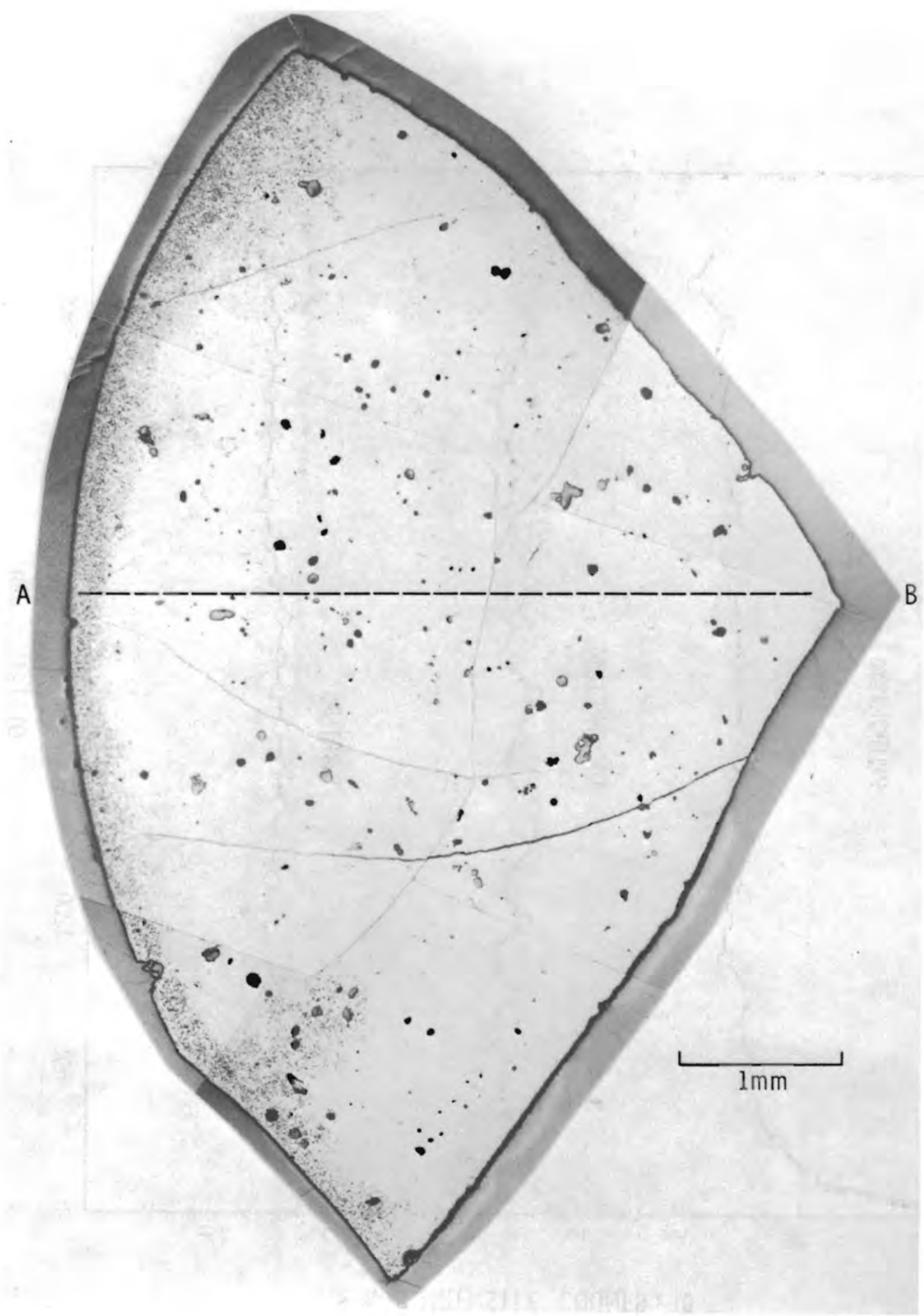

FIGURE 2. Fragment of HB Robinson II Fuel, 28,000 MWd/MTU, Showing Microprobe Step-Scanning Path From point $A$ to point $B$ (Edge to Center)

$$
A-B \cong 4.1 \text { mon }
$$




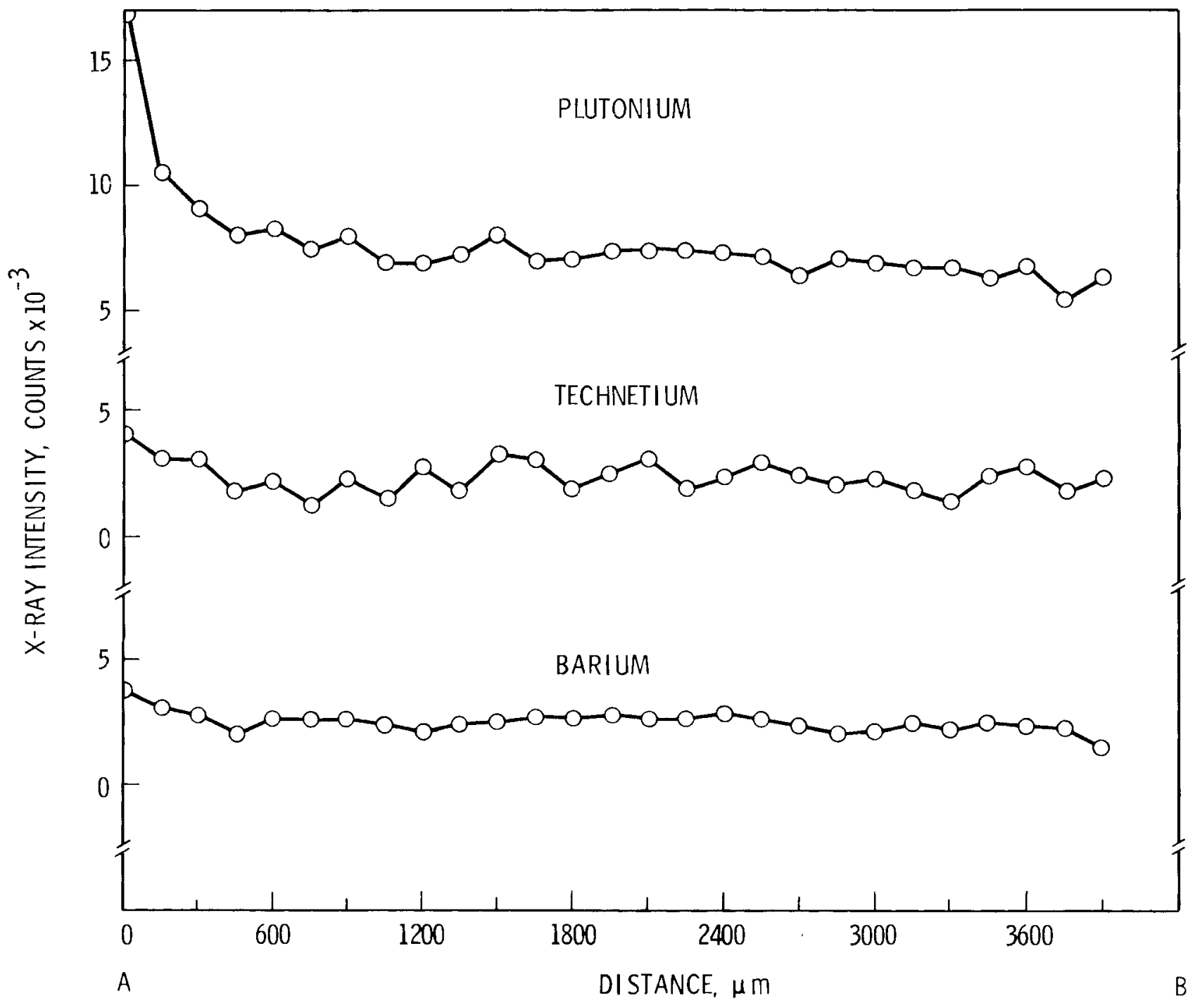

FIGURE 3. Microprobe Measured X-Ray Intensities for Plutonium, Technetium and Barium 


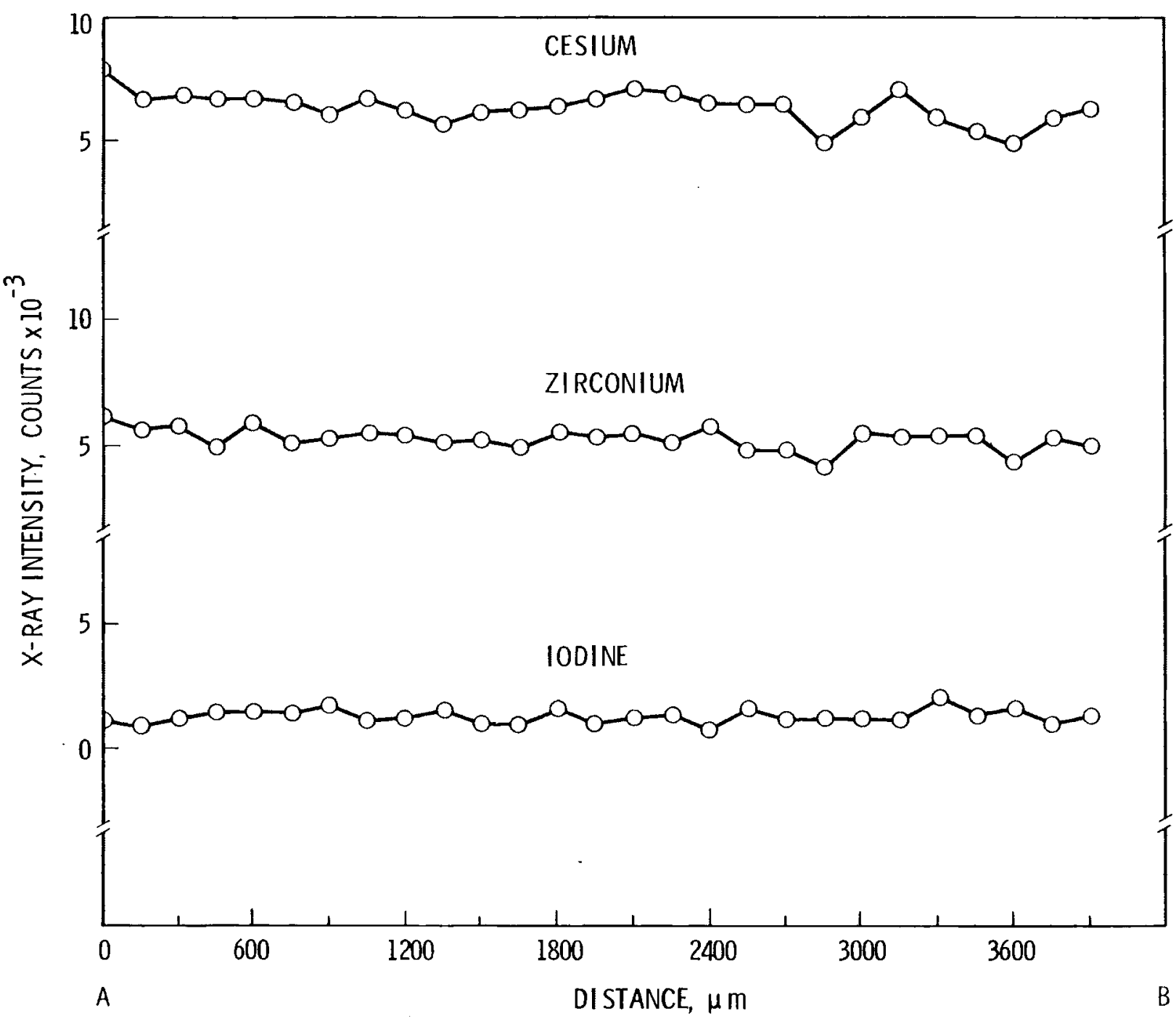

FIGURE 4. Microprobe Measured X-Ray Intensities for Cesium, Zirconium and Iodine 


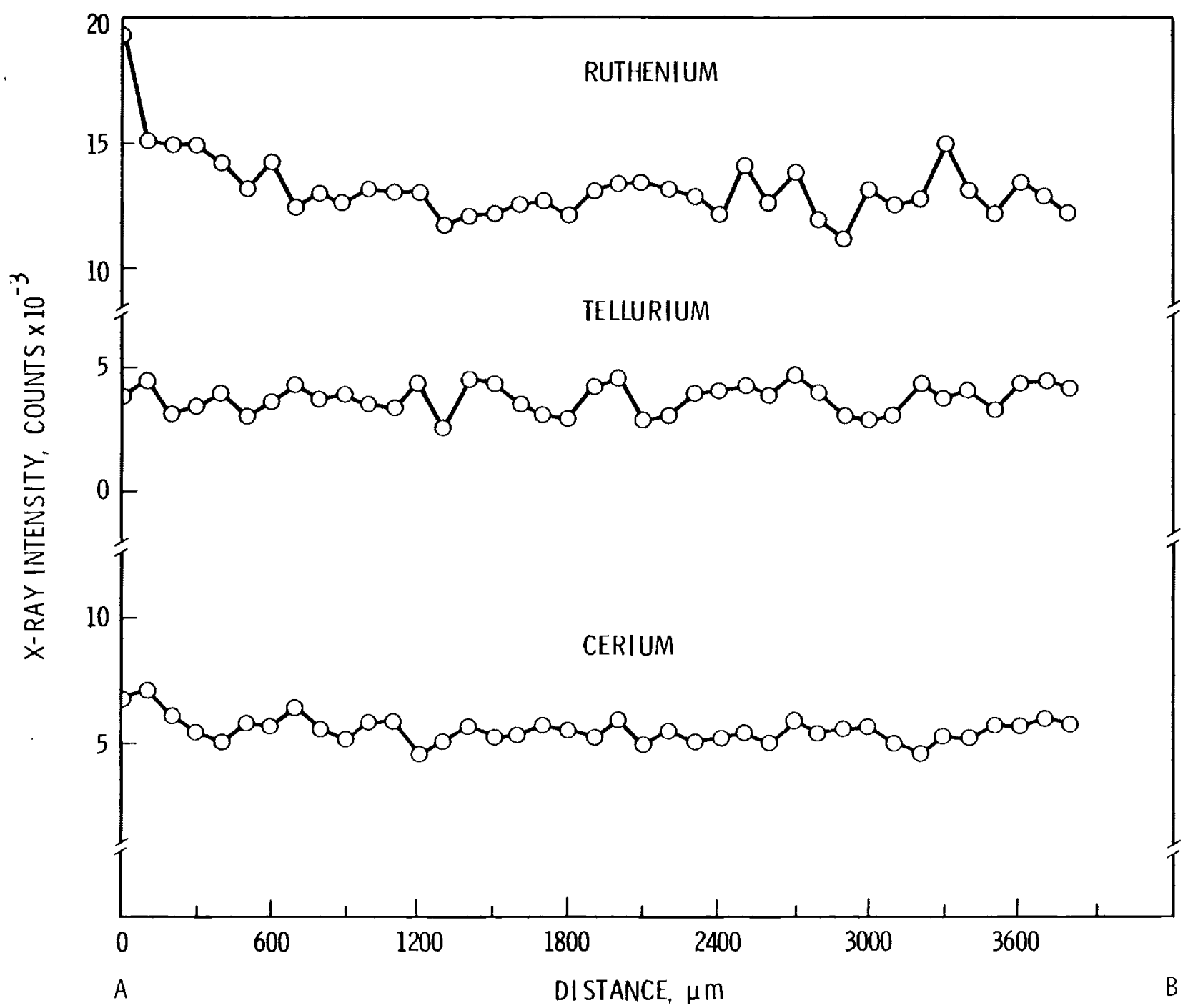

FIGURE 5. Microprobe Measured X-Ray Intensities for Ruthenium, Tellurium and Cerium 
fuel-solution interface. Thus, the transfer of radionuclides to the bulk of the leach solution may not be wholly dependent on diffusion. Table 2 shows the sampling schedule for the IAEA test used.

Approximately $15 \mathrm{~g}$ of fuel fragments (see Figure 6), having a geometric surface area of approximately $30 \mathrm{~cm}^{2}$, were used per test. Figure 7 shows the details of the leach-test container. For these tests the solution volume was $300 \mathrm{ml}$. The solutions used for the spent-fuel leach tests were:

- salt brine, WIPP "B" salt brine (Dosch and Lynch 1978)

- synthetic high-ionic-strength calcium groundwater $\left(0.015 \mathrm{M} \mathrm{CaCl}{ }^{2}\right)$

- synthetic high-bicarbonate groundwater $\left(0.03 \mathrm{M} \mathrm{NaHCO}_{3}\right)$

- synthetic high-ionic-strength sodium groundwater $(0.03 \mathrm{M} \mathrm{NaCl})$

- de ionized water.

Table 3 shows the composition of WIPP "B" salt brine.

\section{ANALYTICAL PROCEDURE}

The tests were run in triplicate, making a total of 15 tests. On each sample collection day, the basket holding the spent-fuel fragments was carefully removed, and after swirling the jar of solution, a 10-ml sample of solution was withdrawn. This sample was then acidified to approximately $\mathrm{pH} 1$ using concentrated nitric acid to prevent radionuclides from adhering to the walls of the glass sample-container. The addition of nitric acid was found to be effective in preventing nuclide plateout in IAEA leach testing of doped glass beads (Bradley, Harvey and Turcotte 1979).

After discarding the remaining leach solution, the leach-test polypropylene jars (see Figure 7) were then filled with $300 \mathrm{ml}$ of $5 \mathrm{M} \mathrm{HNO}_{3}+0.5 \mathrm{M} \mathrm{HF}$. This solution was used to remove any radionuclides that had adhered to the leach-test jar walls. After one to two days, a 10-ml sample was withdrawn and analyzed. The result of this radionuclide concentration analys is was added to that from the original leach solution to arrive at a leach rate of a given radionuclide from the spent fuel. The measurements of radionuclides were all made using common radiochemical analysis methods. Gamma emitters were measured by gamma-energy analysis using a multi-channel analyzer with a Ge-Li detector. 
TABLE 2. IAEA Leach-Test Schedule

\begin{tabular}{|c|c|c|}
\hline $\begin{array}{c}\text { Cumulative Days } \\
\text { Leached }\end{array}$ & $\begin{array}{l}\text { Solution Change, } \\
\text { Series Number }\end{array}$ & $\begin{array}{l}\text { Leach Solutions } \\
\text { to be Analyzed } \\
\end{array}$ \\
\hline 1 & 1 & $x^{(a)}$ \\
\hline 2 & 2 & $x^{(a)}$ \\
\hline 3 & 3 & $x^{(a)}$ \\
\hline 4 & 4 & $x^{(a)}$ \\
\hline 11 & 5 & $x^{(a)}$ \\
\hline 18 & 6 & $x$ \\
\hline 25 & 7 & $x^{(a)}$ \\
\hline 32 & 8 & $x$ \\
\hline 39 & 9 & \\
\hline 46 & 10 & $x$ \\
\hline 53 & 11 & \\
\hline 60 & 12 & $x^{(a)}$ \\
\hline 91 & 13 & $x$ \\
\hline 122 & 14 & \\
\hline 154 & 15 & $x^{(a)}$ \\
\hline 187 & 16 & \\
\hline 215 & 17 & $x$ \\
\hline 246 & 18 & \\
\hline 277 & 19 & $x^{(a)}$ \\
\hline 310 & 20 & \\
\hline 341 & 21 & $x$ \\
\hline 374 & 22 & \\
\hline 404 & 23 & $x^{(a)}$ \\
\hline 433 & 24 & \\
\hline 467 & 25 & $x^{(a)}$ \\
\hline 495 & 26 & \\
\hline 529 & 27 & $x$ \\
\hline
\end{tabular}

(a) Results presented in this report. 


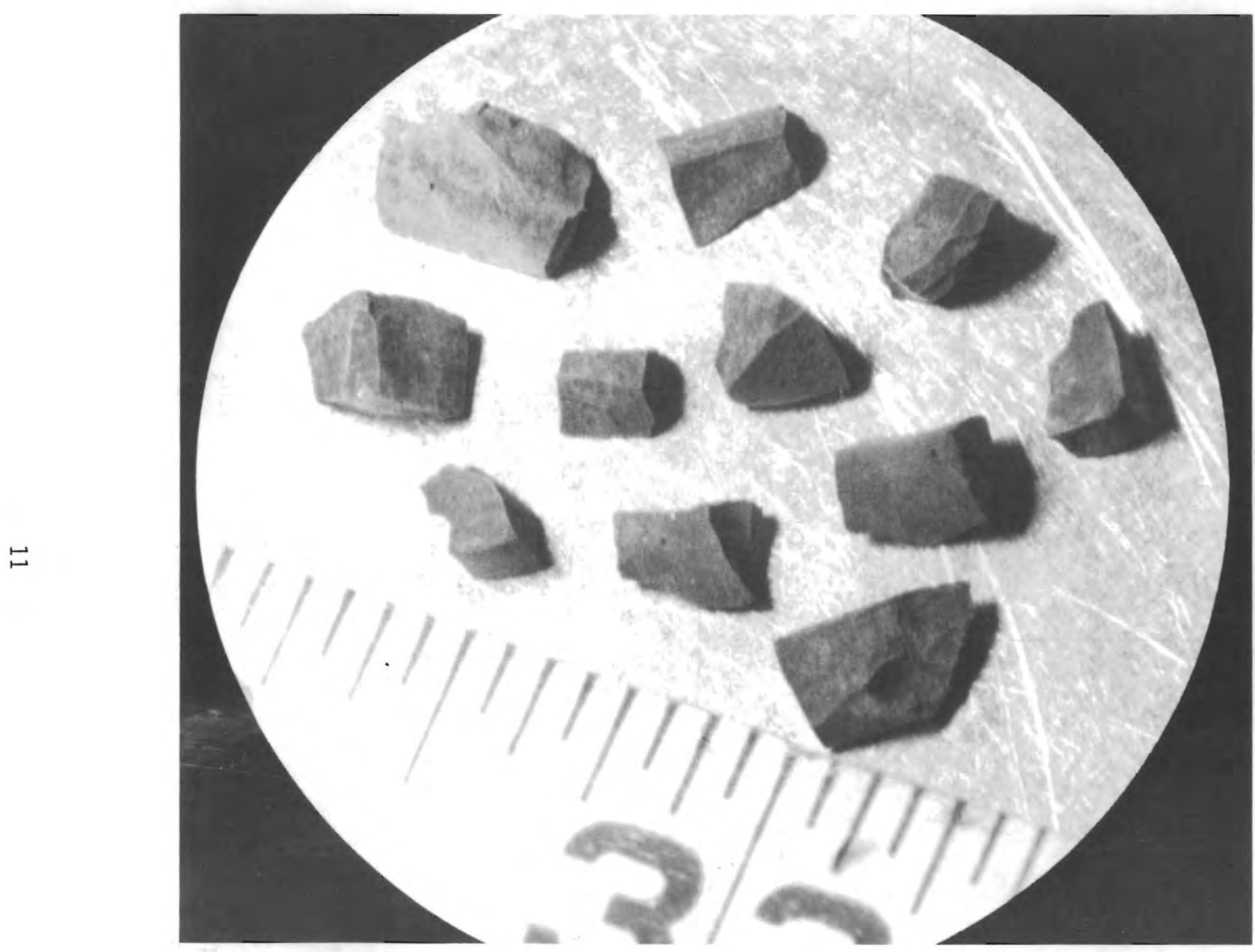

FIGURE 6. Spent LWR Fuel Fragments Photographed Through Hot-Cell Periscope (a)

(a) each division on scale equals $1 / 16$ in. 


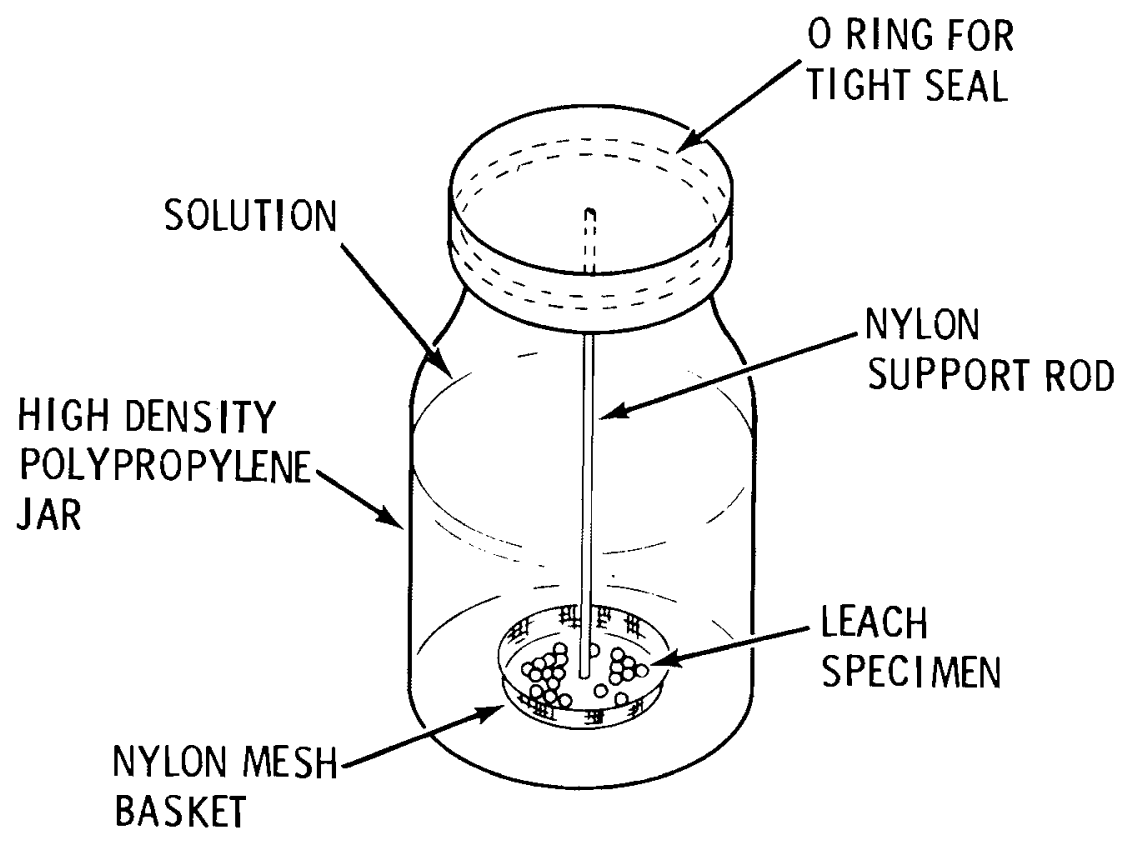

FIGURE 7. IAEA Leach-Test Container

TABLE 3. Chemical and Ionic Composition of Salt Brine(a)

\begin{tabular}{|c|c|c|}
\hline Compound & $\begin{array}{c}\text { Concentration, } \\
\mathrm{g} / \mathrm{L}\end{array}$ & Ion \\
\hline $\mathrm{NaCl}$ & 287.0 & $\mathrm{Na}^{+}$ \\
\hline $\mathrm{Na}_{2} \mathrm{SO}_{4}$ & 6.2 & $\mathrm{~K}^{+}$ \\
\hline $\mathrm{Na}_{2} \mathrm{~B}_{4} \mathrm{O}_{7} \quad 10 \mathrm{H}_{2} \mathrm{O}$ & 0.0160 & $\mathrm{Rb}^{+}$ \\
\hline $\mathrm{NaHCO}_{3}$ & 0.0140 & $\mathrm{Cs}^{+}$ \\
\hline $\mathrm{NaBr}$ & 0.5200 & $\mathrm{Mg}^{++}$ \\
\hline $\mathrm{KCl}$ & 0.0290 & $\mathrm{Ca}^{++}$ \\
\hline KI & 0.0130 & $\mathrm{Sr}^{++}$ \\
\hline $\mathrm{MgCl}_{2}$ & 0.0400 & $\mathrm{Fe}^{+++}$ \\
\hline $\mathrm{CaCl}_{2} 2 \mathrm{H}_{2} \mathrm{O}$ & 0.0033 & $\mathrm{Cl}^{-}$ \\
\hline $\mathrm{FeCl}_{3}$ & 0.0060 & $\mathrm{Br}^{-}$ \\
\hline $\mathrm{SrCl}_{2} 2 \mathrm{H}_{2} \mathrm{O}$ & 0.0330 & $\mathrm{I}^{-}$ \\
\hline $\mathrm{Rb}_{2} \mathrm{SO}_{4}$ & 0.0016 & $\mathrm{HCO}_{3}^{-}$ \\
\hline $\operatorname{CsCl}$ & 0.0013 & $\mathrm{SO}_{4}$ \\
\hline Total dissolved solids & 297.2 & $\mathrm{~B}\left(\mathrm{BO}_{3}\right.$ \\
\hline
\end{tabular}

Concentration, mole/L

5.0

0.00038

0.000012

0.000008

0.00041

0.022

0.00017

0.000036

4.94

0.0050

0.000079

0.00016

0.036

(a) $\mathrm{pH}($ adjusted $)=6.5$ 
To improve the measurement of minor constituents, the majority of the cesium was removed by extraction with tetraphenylboron in amylacetate (Finston 1961) and the sample recounted.

Plutonium and curium analyses, with the exception of brine samples, were done by alpha-energy analys is of a direct mount of the sample. In brine samples, the plutonium was extracted into TTA-xylene (Moore and Hudgens 1957), plated and counted on an alpha proportional counter. Curium was separated by ion exchange, plated and alpha counted.

Strontium was separated by ion exchange and was beta-counted. Repeat counts were made and the ${ }^{90} \mathrm{Sr}$ was calculated from the ${ }^{90} \mathrm{Y}$ ingrowth (Koltoff and Elving 1966). Uranium analys is was done by fluorometry (Centanni and DeSesa 1956; Price, Perritti and Swaity et al. 1953).

\section{CALCULATIONS}

All the leach rates in this report are incremental leach rates and are average leach rates for the sampling interval. The equation used to calculate the incremental leach rate is as follows:

$$
R_{i}=\frac{a_{i}}{A_{0} S t} \text {, where }
$$

$R_{j}=$ incremental leach rate, $\mathrm{g} / \mathrm{cm}^{2}$-day

$a_{j}=$ activity of isotope in leachate, counts $s^{-1}$

$A_{0}=$ specific activity of isotope in sample before leaching, counts $\mathrm{s}^{-1} \mathrm{~g}^{-1}$

$S=$ geometric surface area of sample, $\mathrm{cm}^{2}$

$t=$ incremental leaching period, days. 


\section{RESULTS/DISCUSSION}

Figures 8 through 16 are graphs of incremental leach rates for nine radioactive elements plotted as a function of time. In each figure, leach curves for the five leachants are shown for one element. Each data point represents the average of three samples, and tabulations of the data are given in the Appendix. The elemental leach curves for the five solutions diverge with cumulative leaching time, and for the elements analyzed the spread in the leach rate curves is greatest at the last data point reported (467 days). The leach rates based on cesium, antimony and ruthenium release appear to be the least affected by the different leach solutions. For the other six elements, the leach rate curves for the five different leach solutions are spread out up to 2-1/2 orders of magnitude. The leach rate curves in Figures 8 through 16 are sumarized in Table 4 . Table 4 contains a tabulation of the observed ranking of leach solutions from the highest to lowest elemental releases. Deionized water had the highest release for all the isotopes. The lowest release for the isotopes was in $\mathrm{CaCl}_{2}$ solution except for cerium, ruthenium and europium where the $\mathrm{CaCl}_{2}$ solution was next to lowest.

Figure 17 is a graph of leach rate curves in deionized water for the nine

elements measured. The spread in the curves at the first day of leaching covers two orders of magnitude and decreases to a spread of one order of magnitude at 467 days of cumulative leaching. Cesium has the highest initial leach rate and continues to exhibit a high leach rate at the last sampling period. Ruthenium has the lowest initial leach rate and continues to exhibit the lowest leach rate after 467 days.

Figure 18 is a graph of leach rate curves in $0.03 \mathrm{M} \mathrm{NaCl}$ solution for the nine elements measured. The spread in the leach curves at the first day of leaching covers about 1-1/2 order of magnitude and decreases to about one order of magnitude at 467 days of cumulative leaching. Cesium tends to have the highest leach rate and ruthenium the lowest leach rate during the 467 days, which is the same general behavior as in deionized water. 


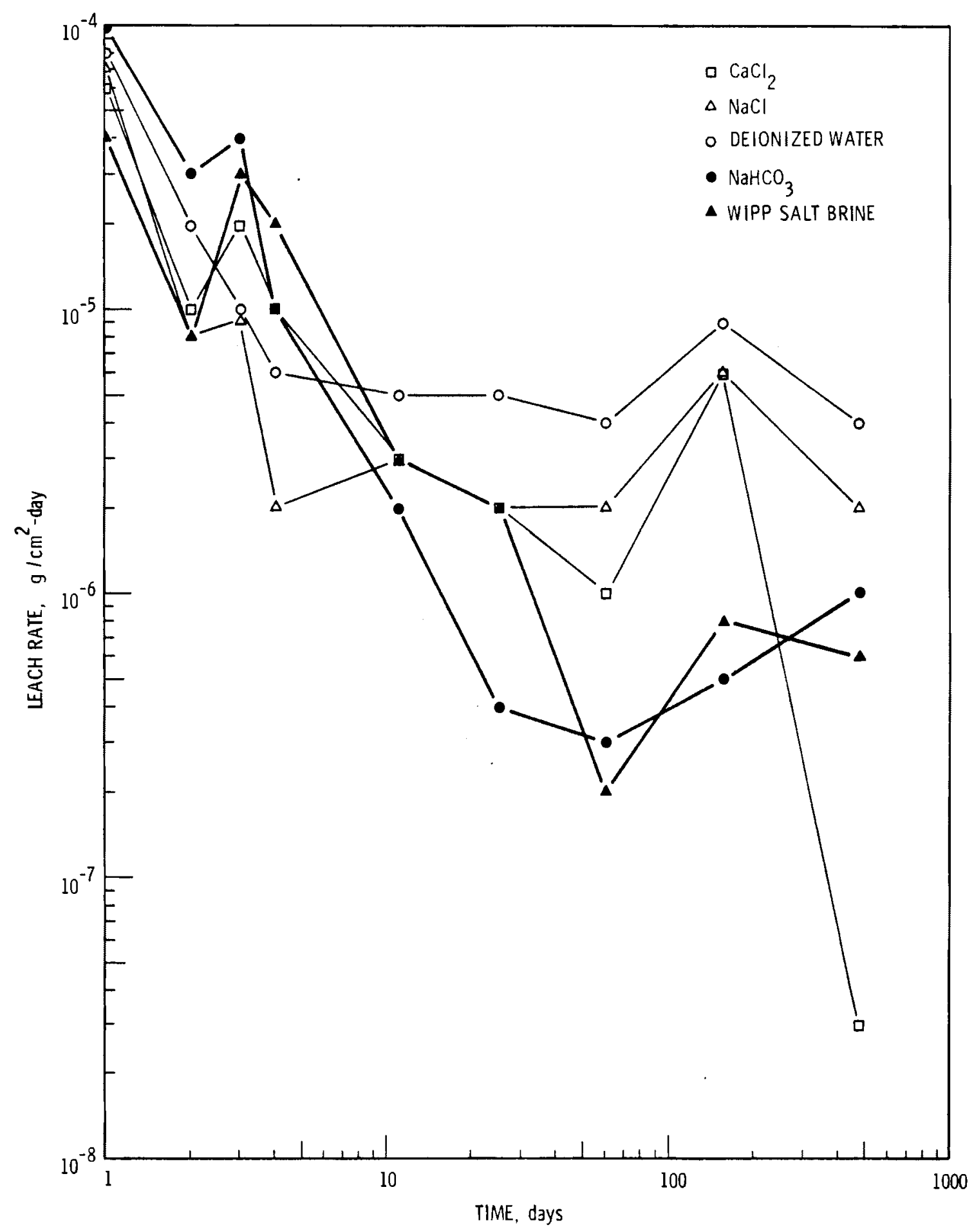

FIGURE 8. Leach Rate of 28,000 MWd/MTU Spent Fuel at $25^{\circ} \mathrm{C}$ Based on Release of Uranium 


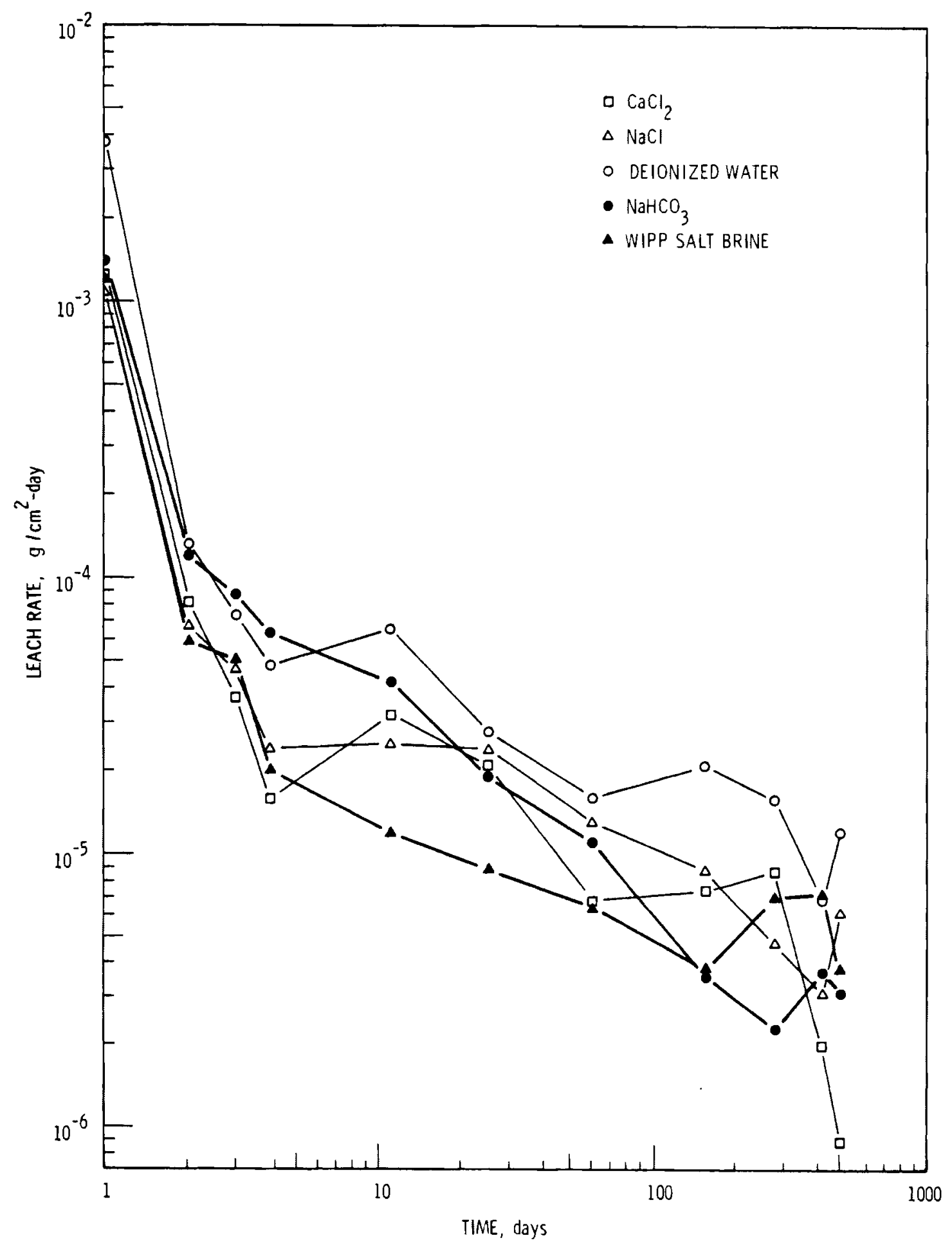

FIGURE 9. Leach Rate of 28,000 MWd/MTU Spent Fue 1 at $25^{\circ} \mathrm{C}$ Based on Release of $137 \mathrm{Cs}$ 


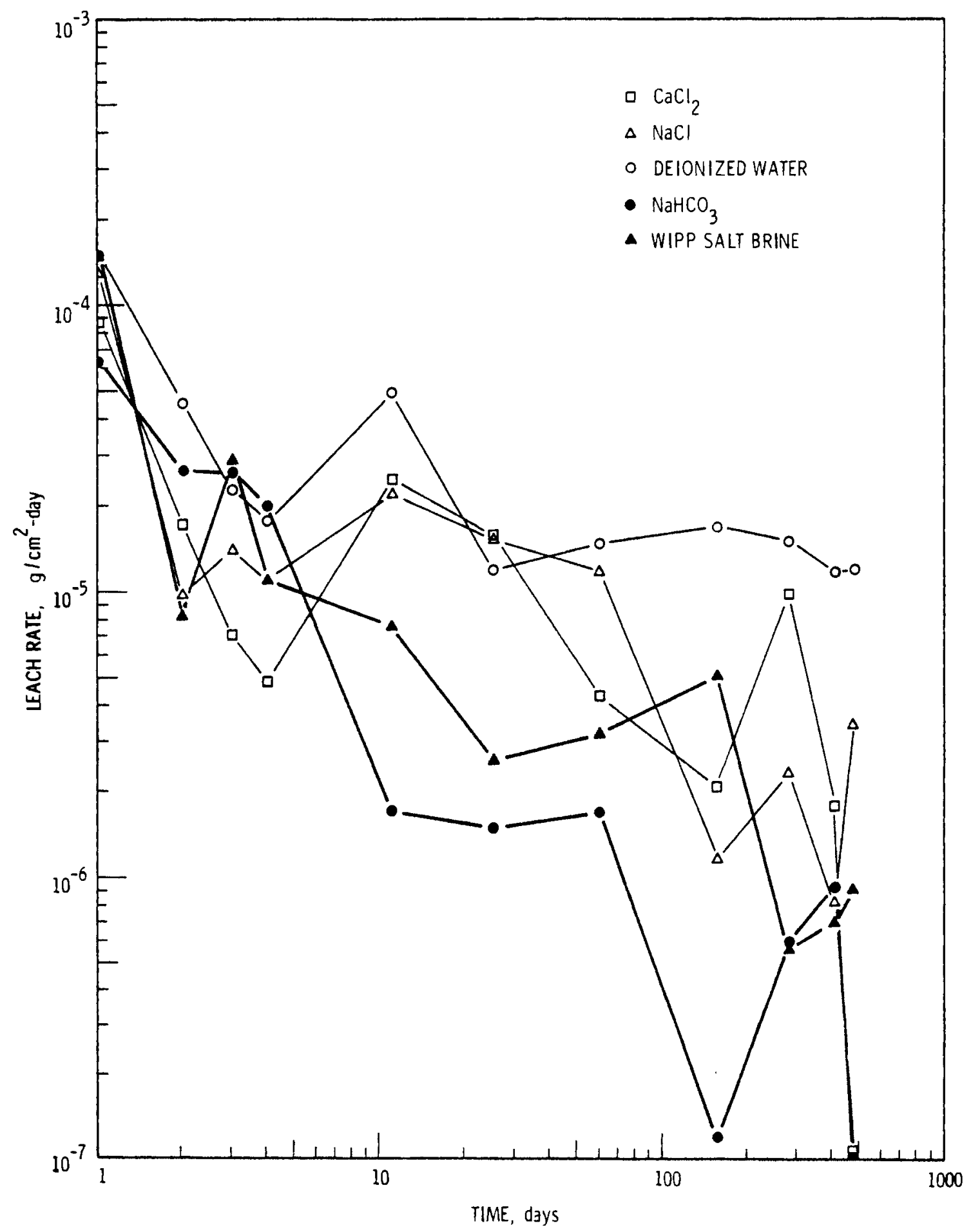

FIGURE 10. Leach Rate of 28,000 MWd/MTU Spent Fuel at $25^{\circ} \mathrm{C}$ Based on Release of ${ }^{144} \mathrm{Ce}$ 


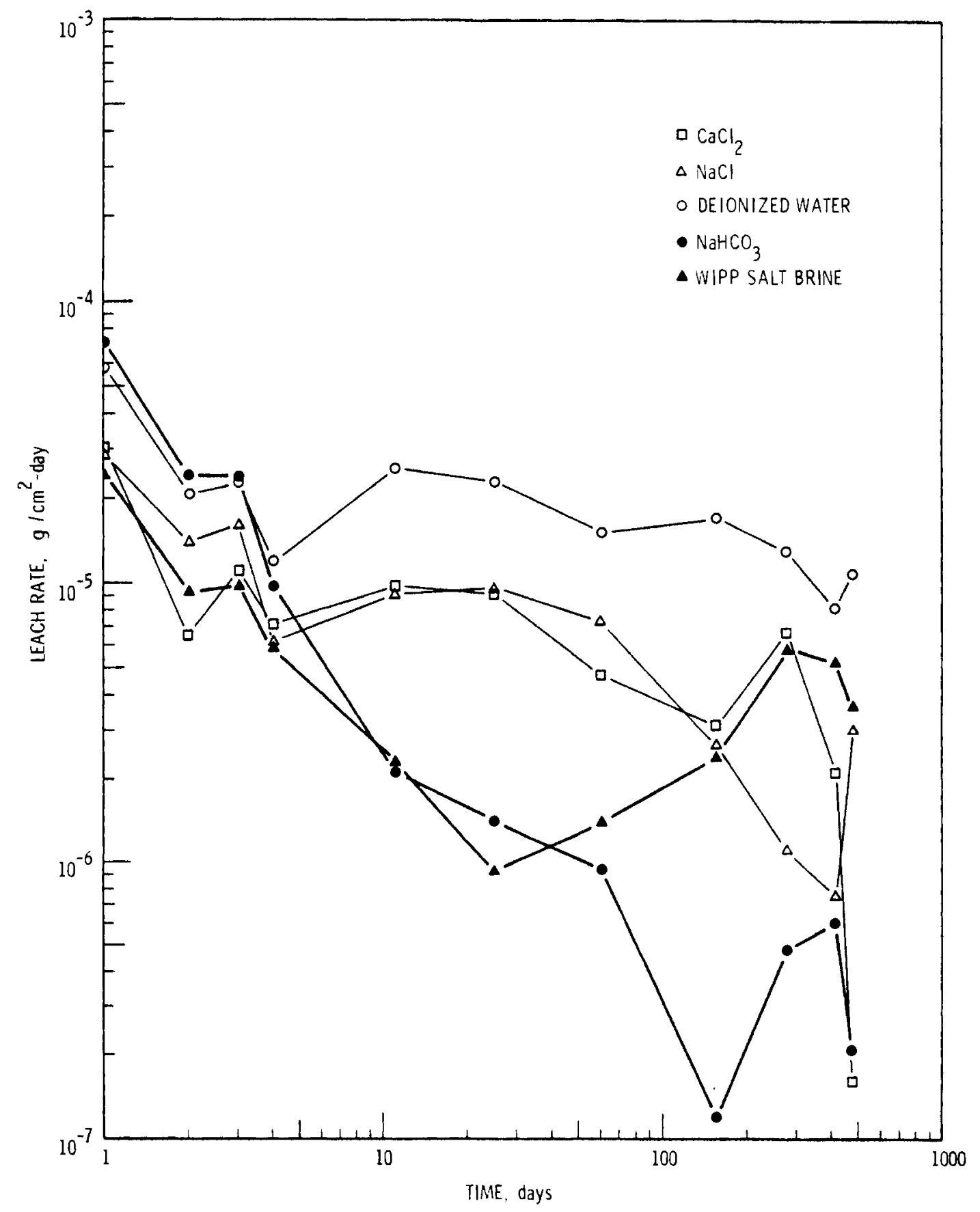

FIGURE 11. Leach Rate of 28,000 MWd/MTU Spent Fue 1 at $25^{\circ} \mathrm{C}$ Based on Release of $239+240 \mathrm{pu}$ 


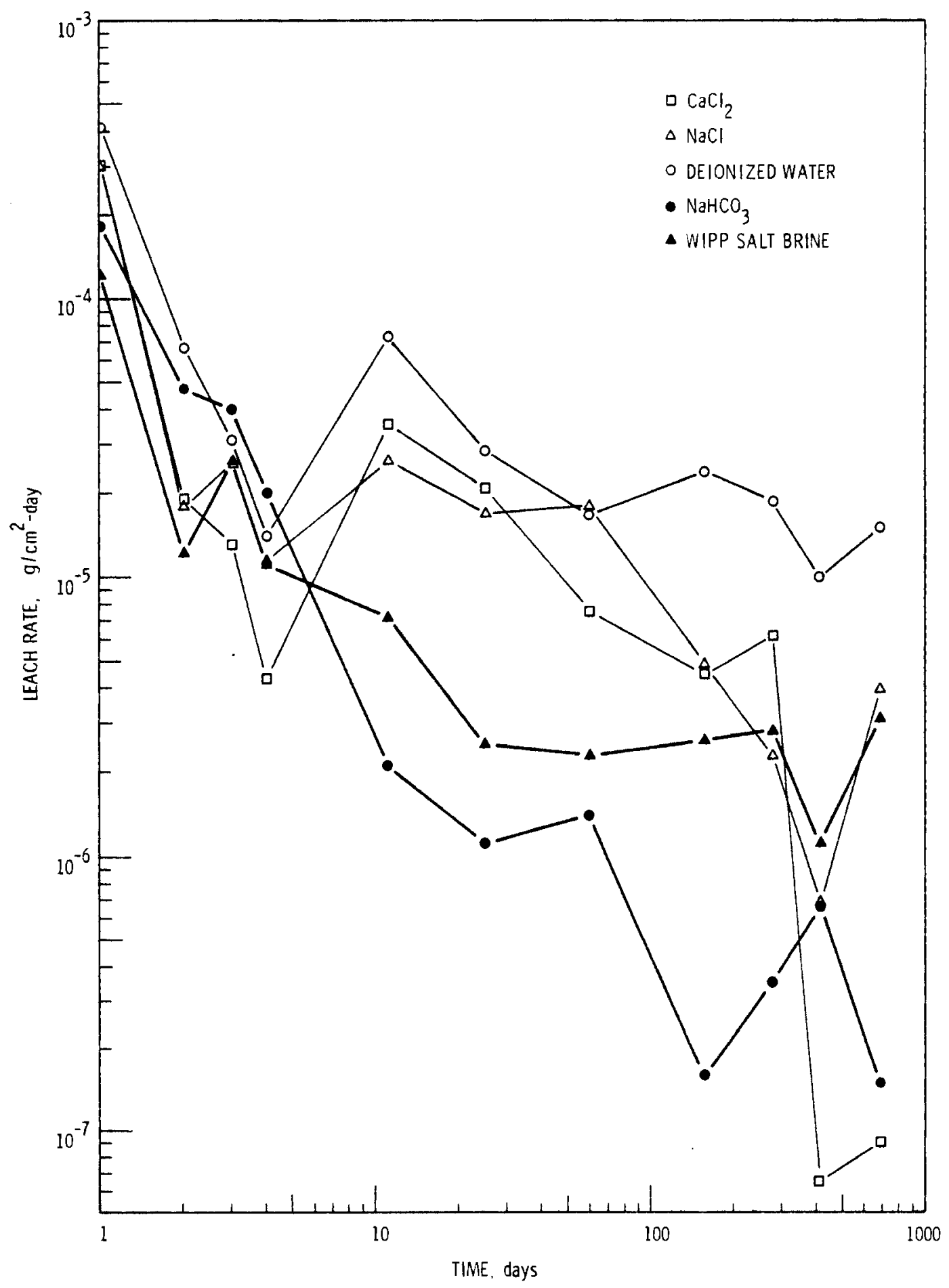

FIGURE 12. Leach Rate of 28,000 MWd/MTU Spent Fue 1 at $25^{\circ} \mathrm{C}$ Based on Release of $244 \mathrm{Cm}$ 


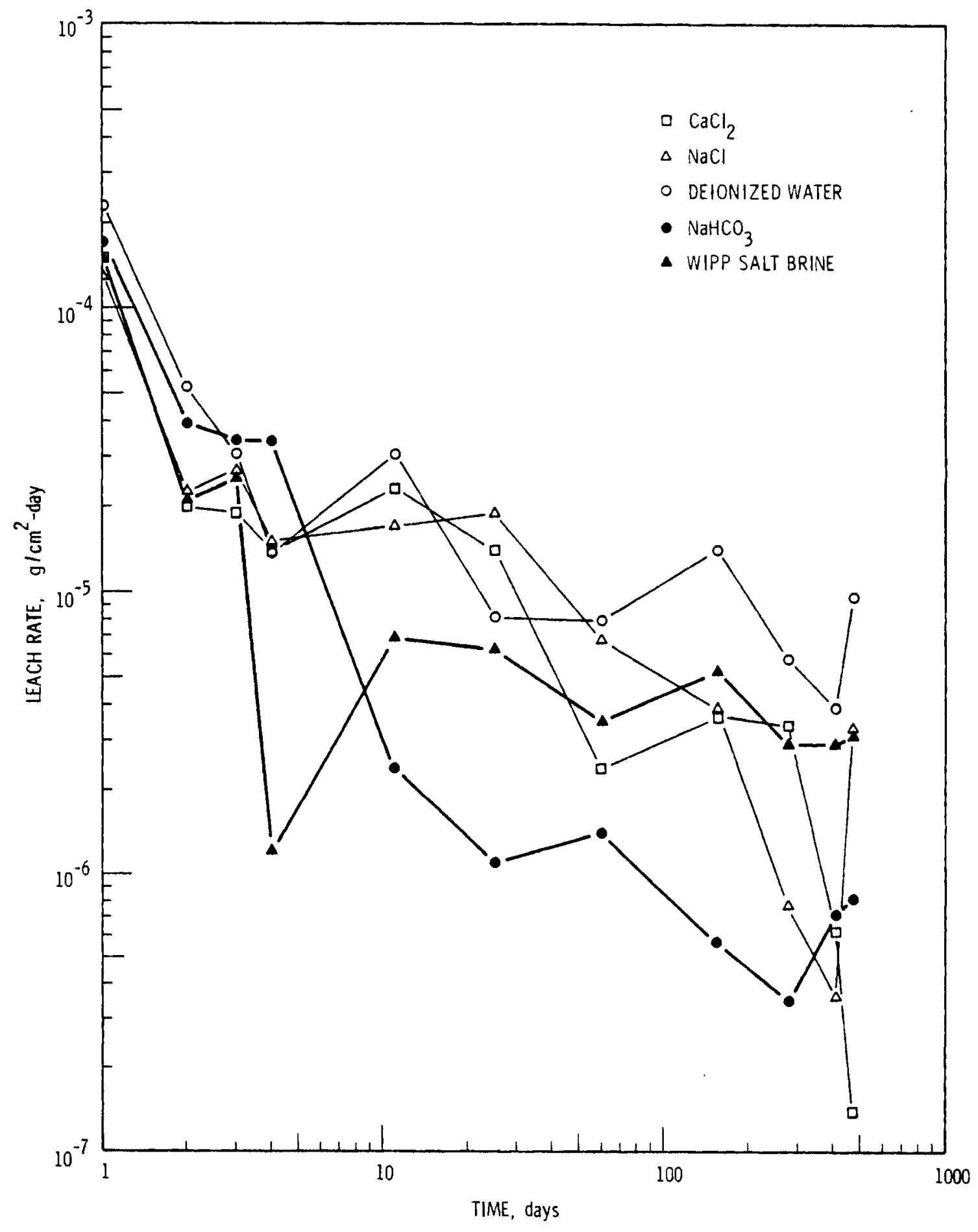

FIGURE 13. Leach Rate of $28,000 \mathrm{MWd} / \mathrm{MTU}$ Spent Fuel at $25^{\circ} \mathrm{C}$ Based on Release of $90 \mathrm{Sr}+90 \mathrm{Y}$ 


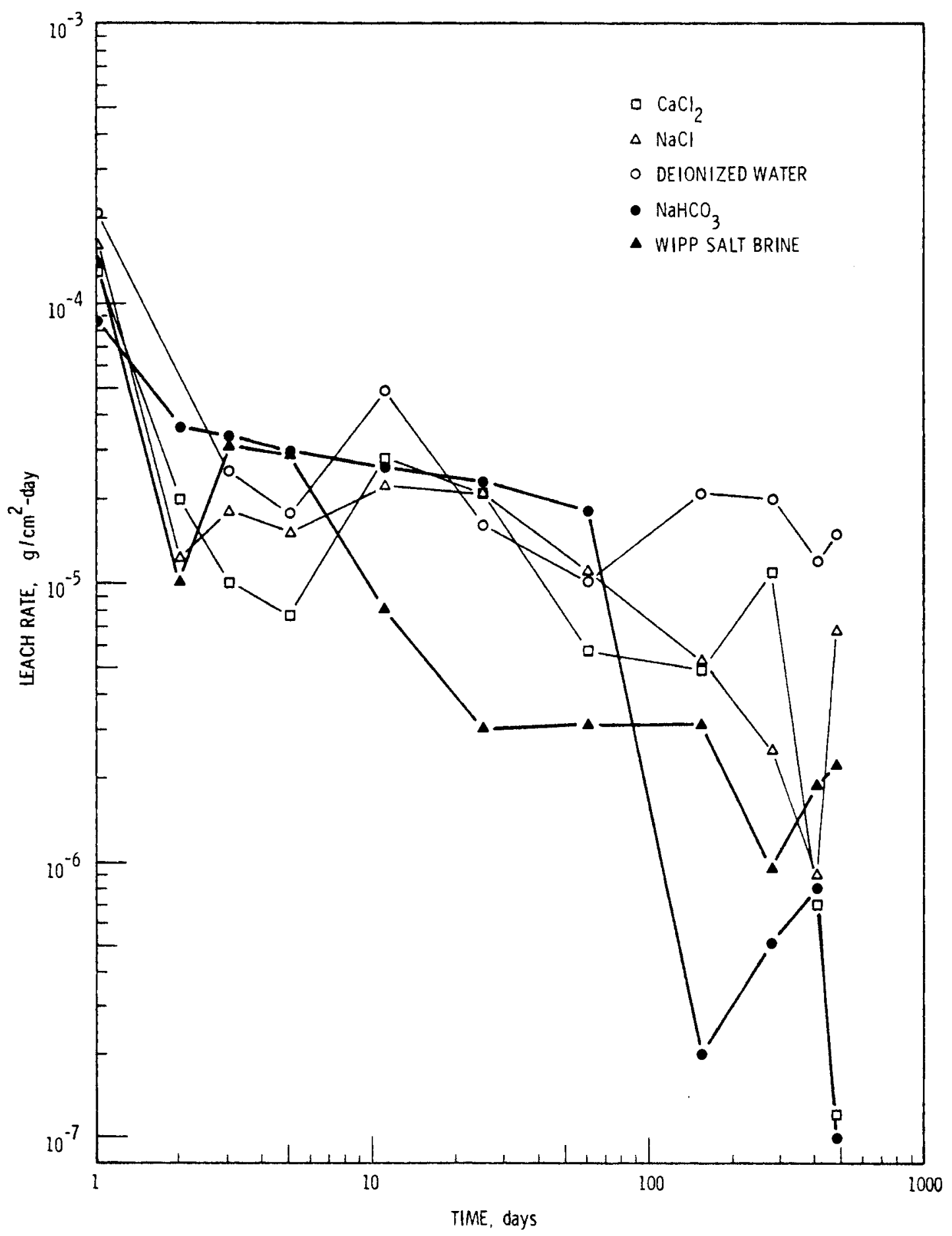

FIGURE 14. Leach Rate of 28,000 MWd/MTU Spent Fuel at $25^{\circ} \mathrm{C}$ Based on Release of 154Eu 


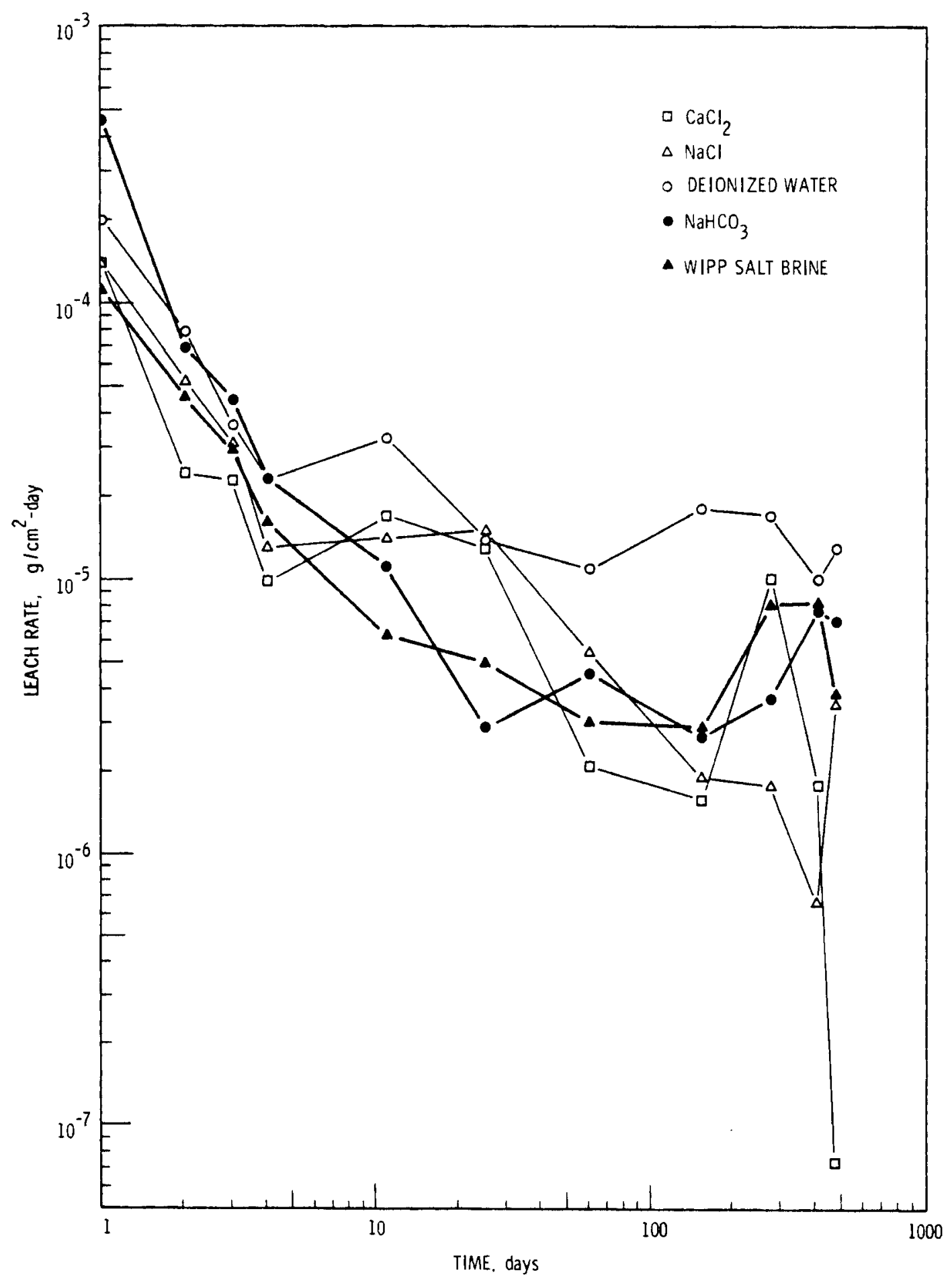

FIGURE 15. Leach Rate of 28,000 MWd/MTU Spent Fuel at $25^{\circ} \mathrm{C}$ Based on Release of ${ }^{125} \mathrm{Sb}$ 


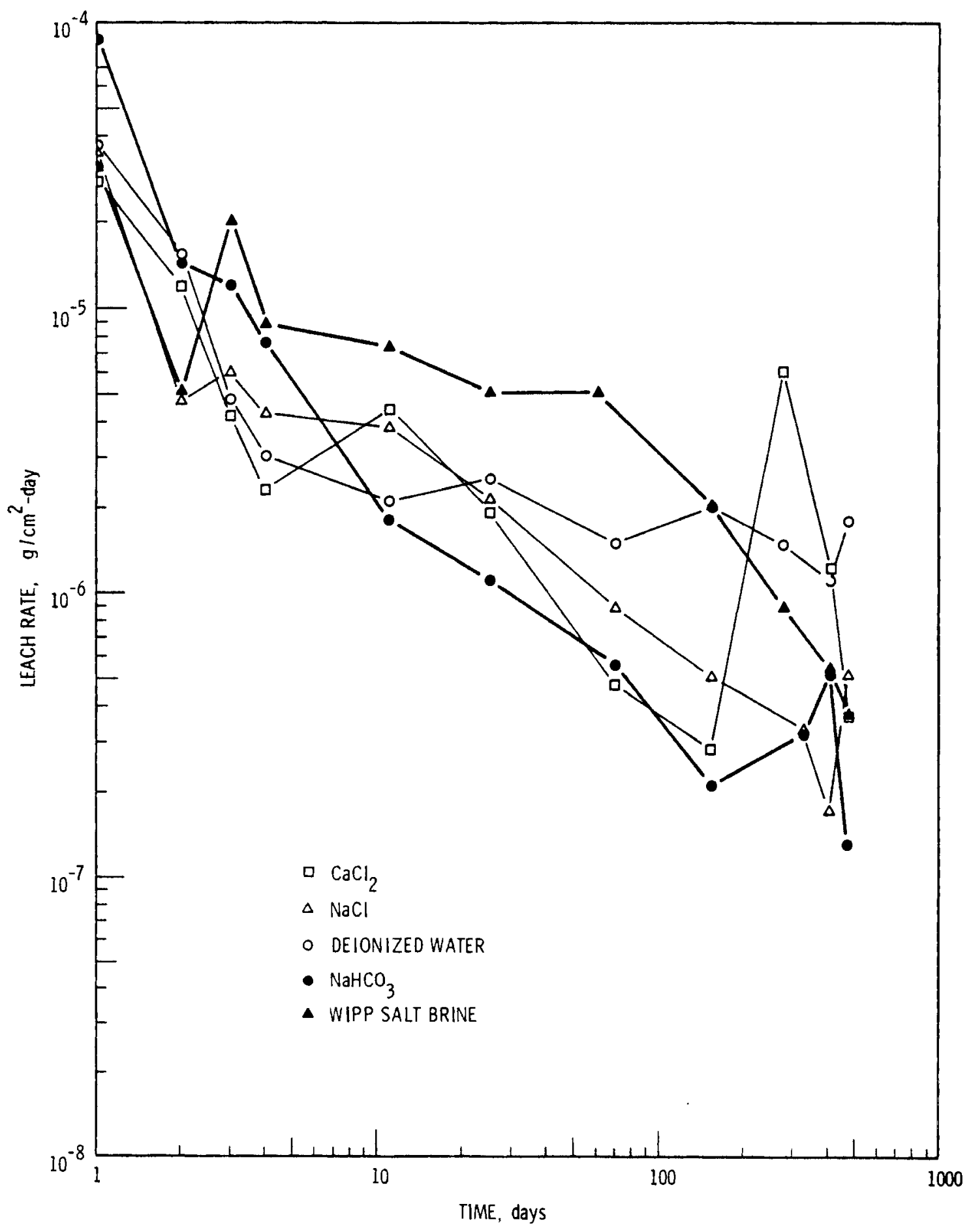

FIGURE 16. Leach Rate of 28,000 MWd/MTU Spent Fuel at $25^{\circ} \mathrm{C}$ Based on Release of $106_{\mathrm{Ru}}$ 
TABLE 4. Results of Effects of Solution Type on Each

Element (Figures 8 through 16)

\begin{tabular}{|c|c|}
\hline Element & $\begin{array}{l}\text { Observed Ranking of Solutions } \\
\text { Highest to Lowest Element Release }\end{array}$ \\
\hline $\begin{array}{l}\text { Uranium } \\
137 \mathrm{Cs} \\
144 \mathrm{Ce} \\
240+239 \mathrm{Pu} \\
244 \mathrm{Cm} \\
90 \mathrm{Sr}+90_{Y} \\
154 \mathrm{Eu} \\
125_{\mathrm{Sb}} \\
106_{\mathrm{Ru}}\end{array}$ & $\begin{array}{l}\text { DiW, (a) } \mathrm{NaHCO}_{3}, \mathrm{NaCl}, \text { WIPP, } \mathrm{CaCl}_{2} \\
\text { DiW, } \mathrm{NaCl}, \text { WIPP, } \mathrm{NaHCO}_{3}, \mathrm{CaCl}_{2} \\
\text { DiW, } \mathrm{NaCl}, \text { WIPP, } \mathrm{CaCl}_{2}, \mathrm{NaHCO}_{3} \\
\text { DiW, WIPP, } \mathrm{NaCl}, \mathrm{NaHCO}_{3}, \mathrm{CaCl}_{2} \\
\text { DiW, } \mathrm{NaCl}, \text { WIPP, } \mathrm{NaHCO}_{3}, \mathrm{CaCl}_{2} \\
\text { DiW, } \mathrm{NaCl}, \text { WIPP, } \mathrm{NaHCO}_{3}, \mathrm{CaCl}_{2} \\
\text { DiW, } \mathrm{NaCl}, \text { WIPP, } \mathrm{CaCl}_{2}, \mathrm{NaHCO}_{3} \\
\text { DiW, } \mathrm{NaHCO}, \text { WIPP, } \mathrm{NaCl}_{3} \mathrm{CaCl}_{2} \\
\text { DiW, } \mathrm{NaCl}, \text { WIPP, } \mathrm{CaCl}_{2}, \mathrm{NaHCO}_{3}\end{array}$ \\
\hline
\end{tabular}

(a) DiW = deionized water.

Figure 19 is a graph of leach rate curves in a saturated WIPP "B" brine solution for the nine elements measured. The spread in the leach curves at the first day of leaching covers about 1-1/2 orders of magnitude and decreases to a spread of about one order of magnitude after 467 days of cumulative leaching. Cesium has the highest initial leach rate and continues to stay near the highest value for the 467 days. Ruthenium has the lowest leach rate for the first two days and the last 63 days during the 467 days of cumulative leaching. In between these two low periods, the ruthenium leach rate increases to become the second highest (next to cesium) at 154 days of cumulative leacining.

Figure 20 is a graph of leach rate curves in a $0.03 \mathrm{M} \mathrm{NaHCO}_{3}$ solution for the nine elements measured. The spread in the leach curves at the first day of leaching covers about 1-1/3 order of magnitude and spreads to about two orders of magnitude at 467 days of cumulative leaching. Cesium has the highest initial leach rate and remains the highest until the antimony leach rate overtakes cesium at 200 days. All the other elements are grouped near the lower portion of the spread in the leach curves. 


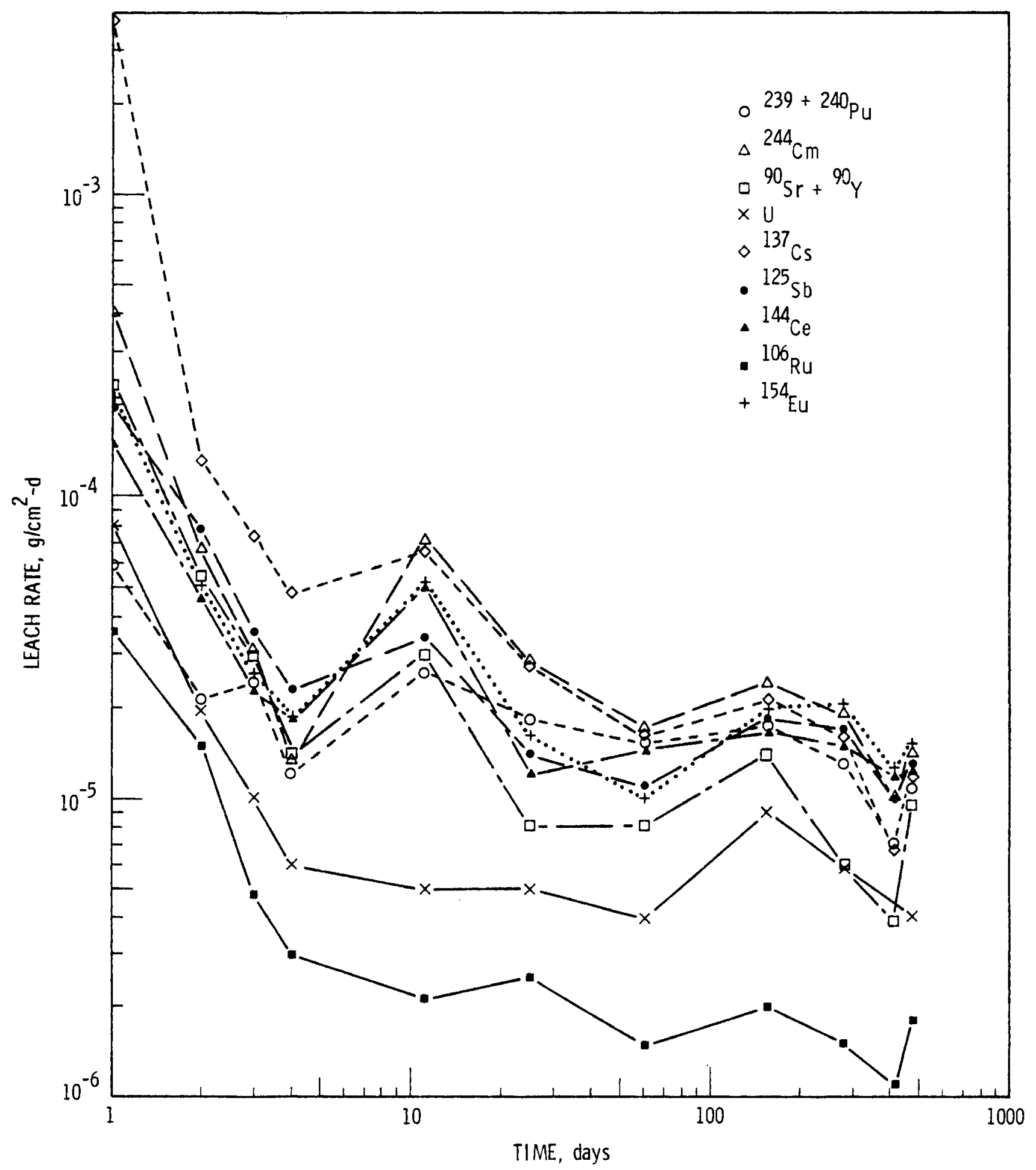

FIGURE 17. Leach Rate of 28,000 MWd/MTU Spent Fue 1 in Deionized Water at $25^{\circ} \mathrm{C}$ Based on Selected Elements 


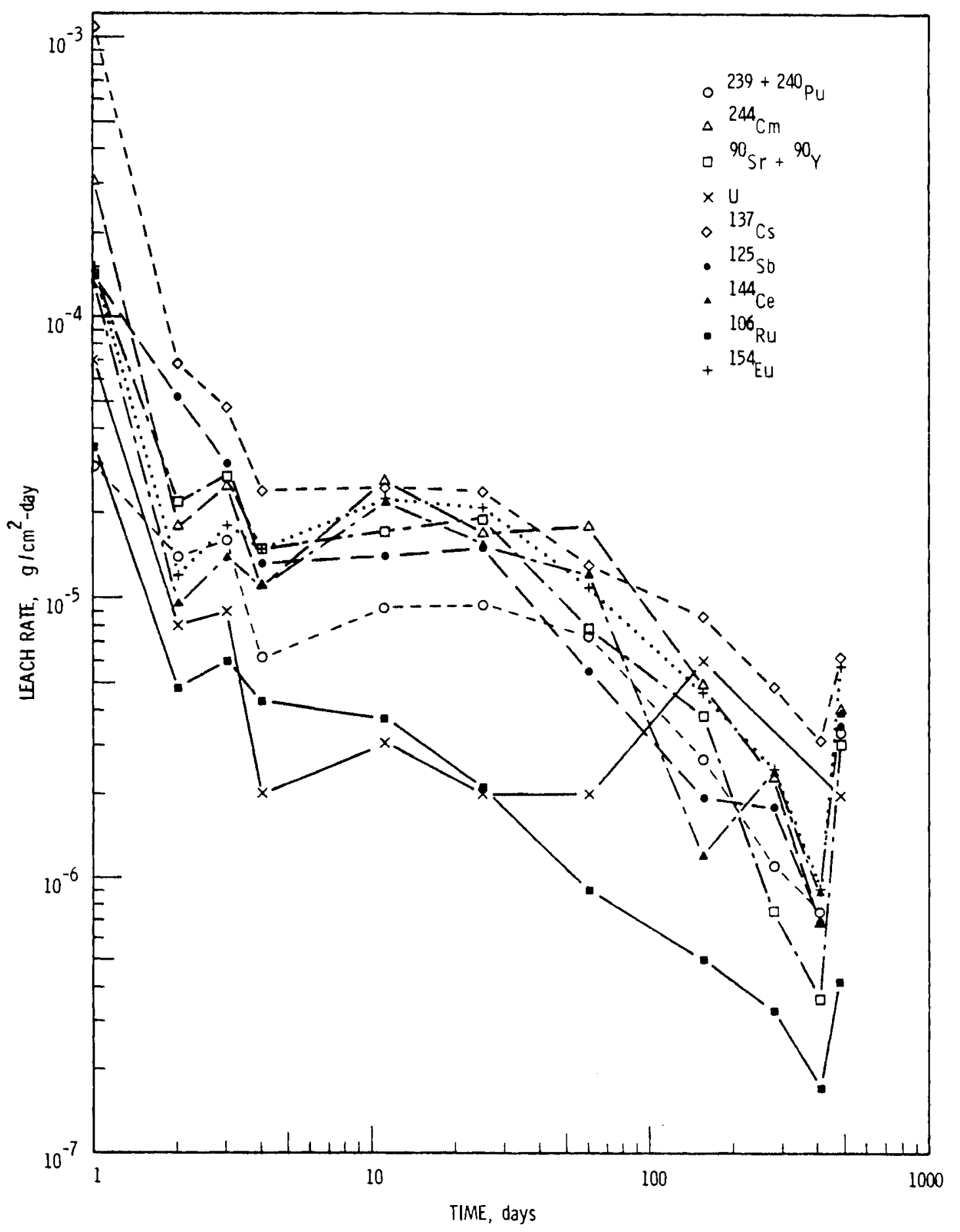

FIGURE 18. Leach Rate of $28,000 \mathrm{MWd} / \mathrm{MTU}$ Spent Fuel in $0.03 \mathrm{M} \mathrm{NaCl}$ at $25^{\circ} \mathrm{C}$ Based on Selected Elements 


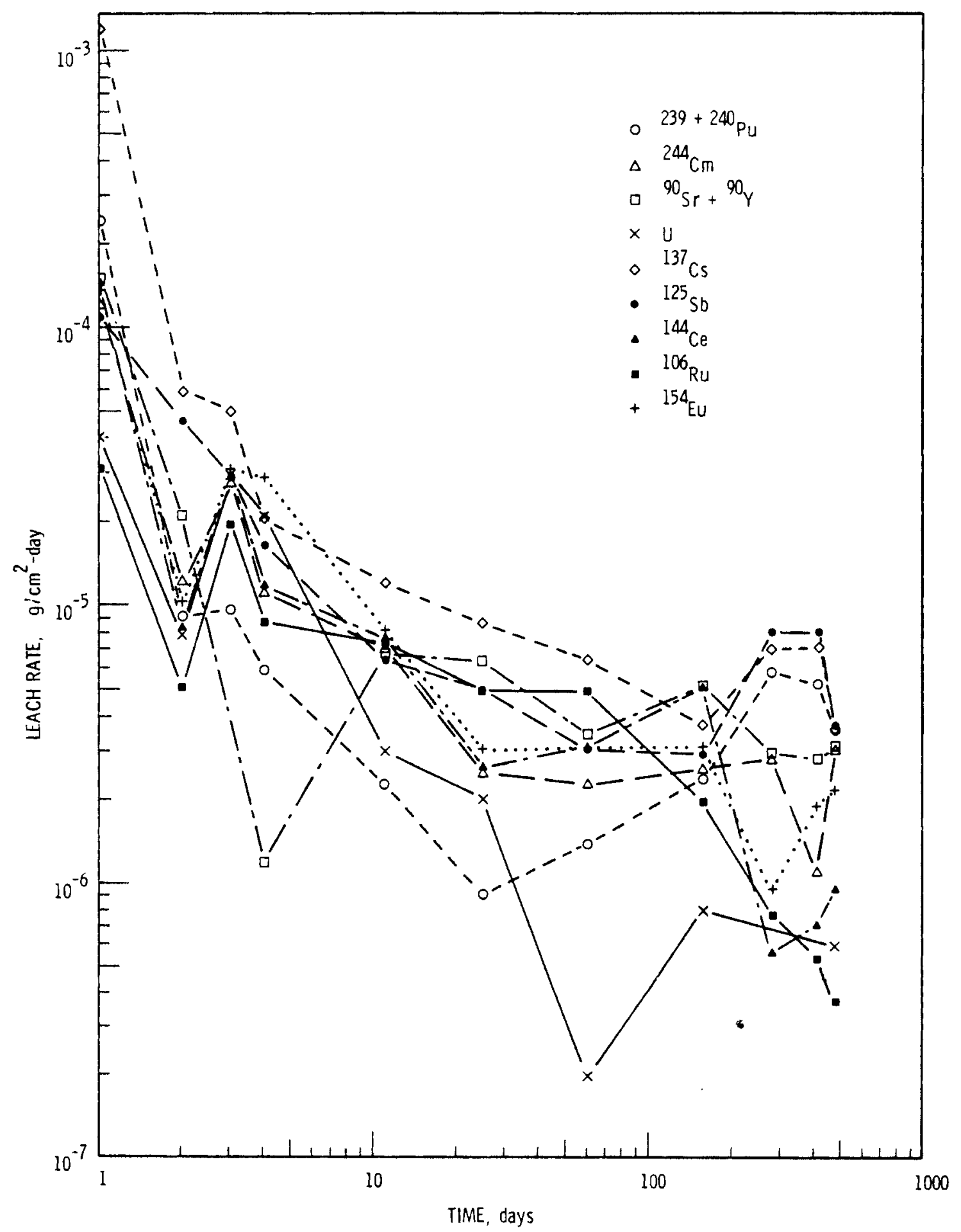

FIGURE 19. Leach Rate of 28,000 MWd/MTU Spent Fuel in WIPP "B" Saturated Brine Solution at $25^{\circ} \mathrm{C}$ Based on Selected Elements 


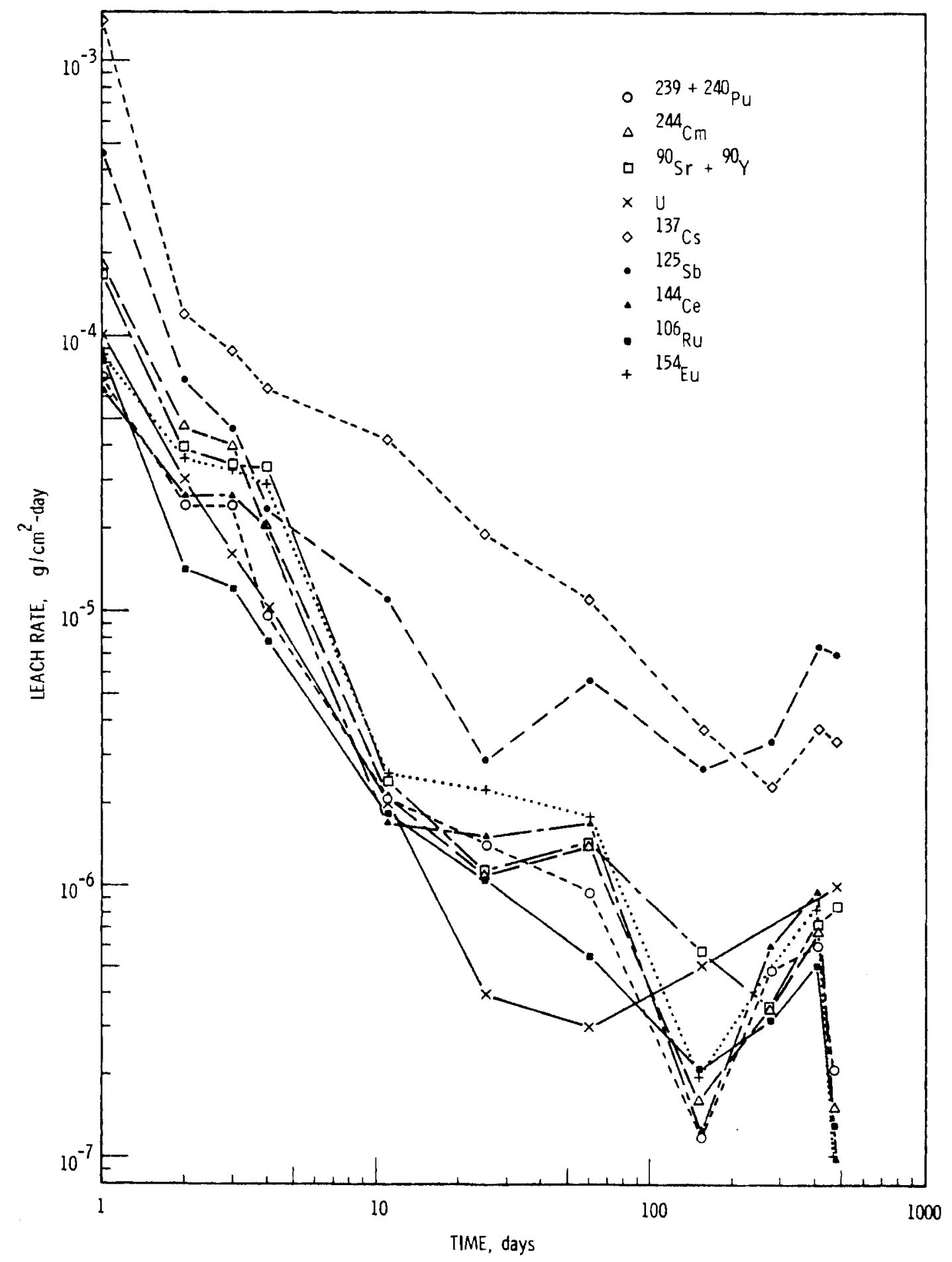

FIGURE 20. Leach Rate of $28,000 \mathrm{MWd} / \mathrm{MTU}$ Spent Fuel in $0.03 \mathrm{M} \mathrm{NaHCO}_{3}$ at $25^{\circ} \mathrm{C}$ Based on Selected Elements 
Figure 21 is a graph of leach rate curves in a $0.015 \mathrm{M} \mathrm{CaCl}_{2}$ solution for the nine elements measured. The spread in the leach curves at the first day of leaching covers about 1-1/2 orders of magnitude, and after 467 days of cumulative leaching the spread is still about 1-1/2 orders of magnitude. After the first week of leaching, the uranium and ruthenium leach curves tend to follow the lower bounds of the spread in the leach curves and the other elements tend to follow the upper portion of the spread.

The elemental leach rate curves for the five leach solutions start at similar values, but the general trends with cumulative time of leaching are lower for the $\mathrm{NaCl}$, WIPP "B" brine. $\mathrm{NaHCO}_{3}$ and $\mathrm{CaCl}_{2}$ solutions than for deionized water. For comparison purposes, if we choose the midpoint of the spread in elemental leach curves after 467 days of cumulative leaching as the average leaching value for that solution, then the relative leachability of the spent fuel in the five leach solutions can be calculated. Table 5 lists the midpoint of the spread in leach curves after 467 days, where the relative leachability value is given with deionized water as a reference of 1.00 . In WIPP " $B$ " brine solution the leach rate of spent fuel is only $20 \%$ of the value in deionized water. The leachability of spent fuel in $0.015 \mathrm{M} \mathrm{CaCl} \mathrm{C}_{2}$ solution is on $1 y 4 \%$ of the rate in deionized water.

In Table 6 the observed ranking of element release from highest to lowest is tabulated based on the incremental leach rate status at 467 days. Cesium is the element with the highest release rate in WIPP "B" brine, $0.015 \mathrm{M} \mathrm{CaCl}_{2}$ and $0.03 \mathrm{M} \mathrm{NaCl}$. It has the second highest release rate in $0.03 \mathrm{M} \mathrm{NaHCO}_{3}$ and ranks fifth in deionized water. Ruthenium is the lowest for all leachants. Uranium and cerium are also low-release elements in all the leachants.

Spent-fuel leach rates measured by the Paige procedure were found to be comparable to the first-generation borosilicate glasses vitrified during the Waste Solidification Engineering Prototype demonstration at PNL (Katayama 1976). Comparisons of spent-fuel and glass leach rates using the IAEA procedures are tabulated in Table 7 . The ${ }^{244} \mathrm{Cm}$ and ${ }^{239+240} \mathrm{Pu}$ based glass leach rates are for a second-generation borosilicate glass coded 76-68 (Bradley, Harvey and Turcotte 1979). In the reference, deionized water leach solution, the spent-fuel leach rates for the actinides plutonium and curium were 50 to 


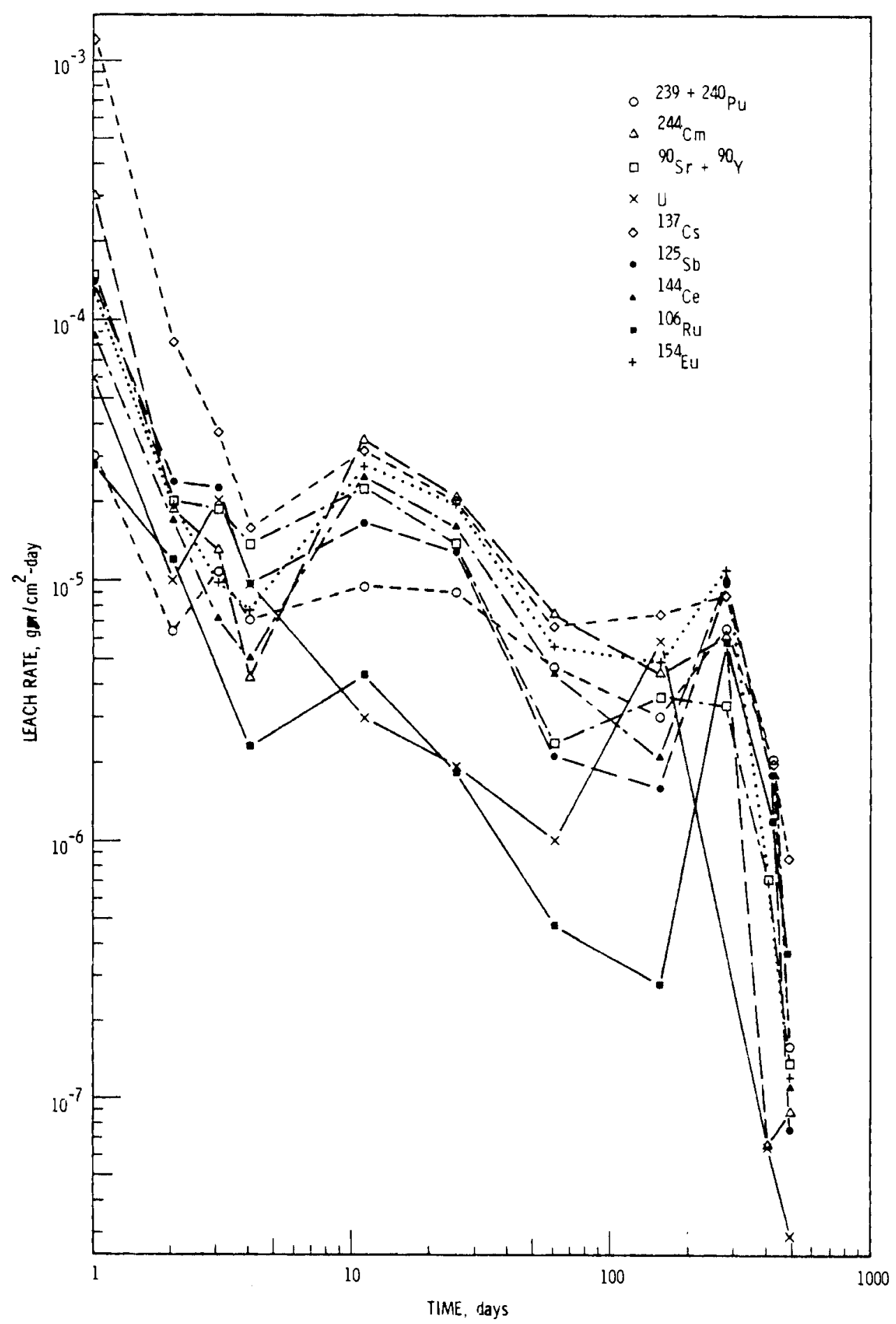

FIGURE 21. Leach Rate of $28,000 \mathrm{MWd} / \mathrm{MTU}$ Spent Fuel in $0.015 \mathrm{M} \mathrm{CaCl} 2$ Solution at $25^{\circ} \mathrm{C}$ Based on Selected Elements 
TABLE 5. Relative Leachability of Spent Fuel in Various Leach Solutions Based on Average Trend of Leach Curves After 467 Days of Cumulative Leaching

\begin{tabular}{|c|c|c|}
\hline Solution & $\begin{array}{c}\text { Midpoint of Leach } \\
\text { Curves at } 467 \text { Days, } \\
\mathrm{g} / \mathrm{cm}^{2}-\text { day } \\
\end{array}$ & $\begin{array}{c}\text { Relative } \\
\text { Leachability } \\
\end{array}$ \\
\hline Deionized Water & $5 \times 10^{-6}$ & 1.00 \\
\hline $0.03 \underline{M ~ N a C l}$ & $2 \times 10^{-6}$ & 0.40 \\
\hline Saturated WIPP "B" & $1 \times 10^{-6}$ & 0.20 \\
\hline $0.03 \underline{M ~ N_{H C O}}$ & $8 \times 10^{-7}$ & 0.16 \\
\hline $0.015 \mathrm{M} \mathrm{CaCl}{ }_{2}$ & $2 \times 10^{-7}$ & 0.04 \\
\hline
\end{tabular}

TABLE 6. Results of Comparing Incremental Leach Rates of Elements for Each Solution Type (Figures 17 through 21)

\begin{tabular}{|c|c|}
\hline Solution & $\begin{array}{l}\text { Observed Ranking of Element Release } \\
\text { From Highest to Lowest ( } 467 \text { Days) } \\
\end{array}$ \\
\hline Deionized Water & $\mathrm{Eu}, \mathrm{Cm}, \mathrm{Sb}, \mathrm{Ce}, \mathrm{Cs}, \mathrm{Pu}, \mathrm{Sr}+\mathrm{Y}, \mathrm{U}, \mathrm{Ru}$ \\
\hline WIPP "B" & $\mathrm{Cs}, \mathrm{Sb}, \mathrm{Pu}, \mathrm{Sr}+\mathrm{Y}, \mathrm{Cm}, \mathrm{Eu}, \mathrm{Ce}, \mathrm{U}, \mathrm{Ru}$ \\
\hline $\mathrm{NaHCO}_{3}$ & $\mathrm{Sb}, \mathrm{Cs}, \mathrm{U}, \mathrm{Sr}+\mathrm{Y}, \mathrm{Pu}, \mathrm{Cm}, \mathrm{Ru}, \mathrm{Eu}, \mathrm{Ce}$ \\
\hline $\mathrm{NaCl}$ & $\mathrm{Cs}, \mathrm{Eu}, \mathrm{Cm}, \mathrm{Ce}, \mathrm{Sb}, \mathrm{Pu}, \mathrm{Sr}+\mathrm{Y}, \mathrm{U}, \mathrm{Ru}$ \\
\hline $\mathrm{CaCl}_{2}$ & $C s, R u, P u, S r+Y, E u, C e, C m, S b, U$ \\
\hline
\end{tabular}

TABLE 7. Comparison of IAEA Leach Rates at $25^{\circ} \mathrm{C}$

\begin{tabular}{|c|c|c|c|c|}
\hline \multirow[b]{2}{*}{ olution } & \multicolumn{2}{|c|}{$\begin{array}{c}240+239 \mathrm{pu} \text { Leach Rates }(\mathrm{a}), \\
\mathrm{g} / \mathrm{cm}^{2} \text {-day }\end{array}$} & \multicolumn{2}{|c|}{$\begin{array}{c}{ }^{244} \mathrm{Cm} \text { Leach Rates (b), } \\
\mathrm{g} / \mathrm{cm}^{2}-\text { day }\end{array}$} \\
\hline & $76-68$ Glass & Spent FueT & $76-68$ Glass & Spent Fut \\
\hline eionized Water & $5 \times 10^{-8}$ & $2 \times 10^{-5}$ & $4 \times 10^{-7}$ & $2 \times 10^{-5}$ \\
\hline WIPP "B" Brine & $2 \times 10-8$ & $2 \times 10^{-6}$ & $1 \times 10^{-8}$ & $3 \times 10^{-6}$ \\
\hline $\mathrm{IaCl}$ & $7 \times 10^{-8}$ & $3 \times 10^{-6}$ & $2 \times 10^{-7}$ & $4 \times 10^{-6}$ \\
\hline $\mathrm{CaCl}_{2}$ & $2 \times 10^{-8}$ & $3 \times 10^{-6}$ & $1 \times 10^{-7}$ & $9 \times 10^{-8}$ \\
\hline $\mathrm{NaHCO}_{3}$ & $2 \times 10^{-7}$ & $1 \times 10^{-7}$ & $2 \times 10^{-7}$ & $2 \times 10^{-7}$ \\
\hline
\end{tabular}

(a) 151 days.

(b) 454 days. 
400 times higher than that of glass. The differences decrease as tests progress from deionized water to the WIPP "B" Brine to the $0.03 \mathrm{M} \mathrm{NaCl}$ solution to the $0.015 \mathrm{M} \mathrm{CaCl}$, solution, and nearly disappear in $0.03 \mathrm{M} \mathrm{NaHCO}_{3}$ solution.

The IAEA leach rates are higher than the published Paige-test leach rates (Katayama 1979) for the same spent fuel after 467 days of cumulative leaching. This comparison is given in Table 8. The IAEA test results are about one order in magnitude higher than the Paige-test results. In WIPP " $B$ " brine $(287 \mathrm{~g} / \mathrm{L}$ $\mathrm{NaCl}$ ) and sodium chloride groundwater $(1.76 \mathrm{~g} / \mathrm{L} \mathrm{NaCl})$, the IAEA cesium-based leach rates are $4 \times 10^{-6}$ and $6 \times 10^{-6} \mathrm{~g} / \mathrm{cm}^{2}$-day, respectively, whereas the Paige cesium-based leach rate in sea brine $(28 \mathrm{~g} / \mathrm{L} \mathrm{NaCl})$ is $6 \times 10^{-7} \mathrm{~g} / \mathrm{cm}^{2}$-day. These differences may be due to radionuclide plate-out on the Paige apparatus, which can not be measured.

The $\mathrm{pH}$ of the deionized water used in the experiment averaged 6.6, and the $\mathrm{pH}$ at the end of the incremental leach period averaged 4.3 . The net result was a decrease in the $\mathrm{pH}$ of the deionized water during the incremental leach test period which averaged $2.3 \mathrm{pH}$ units. This decrease in the $\mathrm{pH}$ value is the opposite of that reported by Grandstaff (1976) for the leaching of uraninite. Such a difference may be due to the difference of chemistry between the spent LWR fuel and the uraninite. Decreases in $\mathrm{pH}$ were also found in the WIPP "B", $0.015 \mathrm{M} \mathrm{CaCl}_{2}$ and $0.03 \mathrm{M} \mathrm{NaCl}$ solutions. Actinide solid-induced radiolys is of similar synthetic groundwater solutions have been observed to cause similar pH drops ( $R a i$ et al. in press). However, increases in $\mathrm{pH}$ were found for the $0.03 \mathrm{M}$ $\mathrm{NaHCO}_{3}$ solution.

There is a subtask in the WRIT program at PNL entitled "Spent-Fuel Special Studies." The major thrust of this task is directed toward understanding the mechanisms and kinetics for spent fuel release in aqueous solutions. The nonun iform release of uranium to the leach solution (see Figure 11), the effects of oxygen, and solubility constraints are being investigated. The progress of these experiments will be presented in the next status report.

The leach rate data presented in this report show that uranium has a lower leach rate than most of the elements studied. This indicates the absence of congruent dissolution. Preliminary results from our electrochemical experiments (part of the Spent-Fuel Special Studies Subtask within WRIT) with fused, 
TABLE 8. Comparison of IAEA Leach Rates to

Paige-Test Leach Rates (467 days)

\begin{tabular}{|c|c|c|c|}
\hline \multirow[b]{2}{*}{ Solution } & \multirow[b]{2}{*}{ Element } & \multicolumn{2}{|c|}{ at $25^{\circ} \mathrm{C}$} \\
\hline & & Paige & IAEA \\
\hline Deionized water & ${ }^{137} \mathrm{Cs}$ & $2 \times 10^{-6}$ & $1 \times 10^{-5}$ \\
\hline Deionized water & $239+240 \mathrm{Pu}$ & $9 \times 10^{-7}$ & $1 \times 10^{-5}$ \\
\hline Deionized water & Uranium & $7 \times 10^{-7}$ & $4 \times 10^{-6}$ \\
\hline Deionized water & ${ }^{244} \mathrm{Cm}$ & $1 \times 10^{-7}$ & $4 \times 10^{-6}$ \\
\hline $\mathrm{NaCl}$ groundwater & ${ }^{137} \mathrm{Cs}$ & -- & $6 \times 10^{-6}$ \\
\hline Sea brine & ${ }^{137} \mathrm{Cs}$ & $6 \times 10^{-7}$ & - \\
\hline WIPP "B" & ${ }^{137} \mathrm{Cs}$ & & $4 \times 10^{-6}$ \\
\hline
\end{tabular}

single crystal $\mathrm{UO}_{2}$ indicates that a film forms on the surface of the $\mathrm{UO}_{2}$ in the standard WRIT leach solutions (those used in this report). If such a hydrolyzed, gelatinous, uranium oxide film forms on the surface of the spent fuel, the uranium release to the leach solution may be lower than the other radionuclides that may pass through this film. The fluctuations in the uranium leach rates presented in this report do not relate to the leach rate trends of the other elements studied. This incongruency in the leach rates lends support to the possibility of a hydrolyzed uranium oxide film forming on our spent-fuel samples. Thus, the observed uranium leach rate may be dependent on the formation, dissolution and partial spallation of such a film. 


\section{CONCLUSIONS}

The leach rates of antimony, cerium, cesium, curium, europium, plutonium, ruthenium, strontium + yttrium, and uranium were determined from LWR spent fue 1 (unclad) with a burnup of 28,000 MWd/MTU in five different leach solutions. These solutions were deionized water, 0.03M sodium chloride solutions, $0.03 \mathrm{M}$ sodium bicarbonate solution, $0.015 \mathrm{M}$ calcium chloride solution and a saturated WIPP "B" brine solution. On the average, of the five solutions studied deionized water produced the highest elemental leach rate. The leach rates in the bicarbonate solution were second lowest, with the $\mathrm{CaCl}_{2}$ solution exhibiting the lowest leach rates. The two brines were intermediate.

Cesium had the highest leach rate in three solutions (WIPP " $\mathrm{B}$ " brine, $0.03 \mathrm{M} \mathrm{NaCl}$ and $\left.1.015 \mathrm{M} \mathrm{CaCl}_{2}\right)$. Europium had the highest leach rate in deionized water and antimony the highest in $0.03 \mathrm{M} \mathrm{NaHCO}_{3}$. Ruthenium had the lowest leach rate in three solutions (deionized water, $0.03 \mathrm{M} \mathrm{NaCl}$ and WIPP "B" brine). Cerium had the lowest elemental leach rate in $0.015 \mathrm{M} \mathrm{NaHCO}_{3}$ and uranium the lowest in $0.03 \mathrm{M} \mathrm{CaCl}_{2}$ solution.

Based on the release of plutonium and curium, spent fue 1 has a leach rate comparable to 76-68 glass in sodium bicarbonate solution and is 50 to 400 times less leach resistant than 76-68 glass in deionized water and WIPP "B" brine solution.

The spent-fuel leach rates calculated from the IAEA procedure are one order of magnitude higher than the values reported for the Paige procedure. The discrepancy may be caused by nuclide plate-out on the walls of the Paige apparatus, which can not be measured during testing. Thus, to be conservative one should perform leaching tests by the modified IAEA procedure rather than the Paige procedure.

The leach rate data in this status report show that spent fuel may not leach congruently with uranium. 


\section{REFERENCES}

Bradley, D. J., C. O. Harvey and R. P. Turcotte. 1979. Leaching of Actinides and Technetium from Simulated High-Level Waste Glass. PNL-3152, Battelle, Pacific Northwest Laboratory, Richland, Washington.

Centanni, Ross A. M. and M. A. DeSesa. 1956. "Fluorimetric Determination of Uranium." Anal. Cheml. 28:1651-1657.

Dosch, R. G., and A. W. Lynch. 1978. Interaction of Radionuclides with Geomedia Associated with the Waste Isolation Pilot Plant (WIPP) Site in New Mexico. SAND 78-0297, Sandia Laboratory, Albuquerque, New Mexico.

Finston, H. L. 1961. "The Radiochemistry of Cesium." Nuclear Science Series. No. 5-NA3085.

Grandstaff, D. E. 1976. "A Kinetic Study of the Dissolution of Uraninite." Econ. Geol. 71:1493-1506.

Katayama, Y. B. 1976. Leaching of Irradiated LWR Fuel Pellets in Deionized and Typical Groundwater. BNWL-2057, Pacific Northwest Laboratories, Richland, Washington.

Katayama, Y. B. 1979. Spent LWR Fuel Leach Test. PNL-2982, Battelle, Pacific Northwest Laboratory, Richland, Washington.

Koltoff, I. M., and R. J. Elving. 1966. Treatise of Anaytical Chemistry, Part I, Vol. 4. Interscience Publishers, Inc., New York, New York.

Mende 1, J. E. 1973. A Review of Leaching Test Methods and the Leachability of Various Solids Media Containing Radioactive Wastes. BNWL-1765, Pacific Northwest Laboratories, Richland, Washington.

Moore, K. L., and J. E. Hudgens, Jr. 1957. "Separation and Determination of Plutonium by Liquid-Liquid Extraction." Anal. Chem. 29:1767.

Price, G. R., G. R. Perretti and S. Swaitz. 1953. "Fluorophotometric Determination of Uranium." Anal. Chem. 25(2):322-331.

Rai, Dhanpat et al., in press. "Solubility of Plutonium Compounds and Their Behavior in Soils," Soil Sci. Soc. Ann. J. 


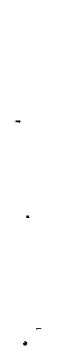


APPENDIX

LEACH DATA 
IAEA LEACH RATE BASED ON $244 \mathrm{~cm}\left(\mathrm{~g} / \mathrm{cm}^{2}\right.$-day)

FOR 28,000 MWd/MTU SPENT FUEL AT $25^{\circ} \mathrm{C}$

\begin{tabular}{|c|c|c|c|c|c|c|}
\hline Series & $\begin{array}{c}\text { Cumulative } \\
\text { Days }\end{array}$ & $\begin{array}{l}\text { WIPP } \\
\text { Brine } \\
\end{array}$ & $\begin{array}{l}\mathrm{CaCl}_{2} \\
\text { Solution } \\
\end{array}$ & $\begin{array}{c}\mathrm{NaCl} \\
\text { Solution } \\
\end{array}$ & $\begin{array}{r}\mathrm{NaHCO}_{3} \\
\text { Solution } \\
\end{array}$ & $\begin{array}{c}\text { Deionized } \\
\text { Water }\end{array}$ \\
\hline 1 & 1 & $1.2 E-4$ & $3.0 E-4$ & $3.0 E-4$ & $1.8 E-4$ & $4.1 E-4$ \\
\hline 2 & 2 & $1.2 E-5$ & $1.9 \mathrm{E}-5$ & $1.8 E-5$ & $4.7 E-5$ & $6.7 \mathrm{E}-5$ \\
\hline 3 & 3 & $2.6 E-5$ & $1.3 E-5$ & $2.5 E-5$ & $4.0 E-5$ & $3.1 E-5$ \\
\hline 4 & 4 & $1.1 E-5$ & $4.3 E-6$ & $1.1 E-5$ & $2.0 E-5$ & $1.4 E-5$ \\
\hline 5 & 11 & $7.1 \mathrm{E}-6$ & $3.5 E-5$ & $2.6 E-5$ & $2.1 E-6$ & $7.2 E-5$ \\
\hline 7 & 25 & $2.5 E-6$ & $2.1 E-5$ & $1.7 E-5$ & $1.1 E-6$ & $2.8 E-5$ \\
\hline 12 & 60 & $2.3 E-6$ & $7.6 E-6$ & $1.8 E-5$ & $1.4 E-6$ & $1.7 \mathrm{E}-5$ \\
\hline 15 & 154 & $2.6 E-6$ & $4.5 E-6$ & $4.9 E-6$ & $1.6 \mathrm{E}-7$ & $2.4 E-5$ \\
\hline 19 & 277 & $2.8 E-6$ & $6.2 E-6$ & $2.3 E-6$ & $3.5 E-7$ & $1.9 E-5$ \\
\hline 23 & 404 & $1.1 E-6$ & $6.7 E-8$ & $6.8 E-7$ & $6.8 E-7$ & $1.0 E-5$ \\
\hline 25 & 467 & $3.1 E-6$ & $9.1 E-8$ & $4.0 \mathrm{E}-6$ & $1.5 \mathrm{E}-7$ & $1.5 E-5$ \\
\hline
\end{tabular}

IAEA LEACH RATE BASED ON $U\left(\mathrm{~g} / \mathrm{cm}^{2}\right.$-day)

FOR 28,000 MWd/MTU SPENT FUEL AT $25^{\circ} \mathrm{C}$

\begin{tabular}{|c|c|c|c|c|c|c|}
\hline Series & $\begin{array}{c}\text { Cumulative } \\
\text { Days } \\
\end{array}$ & $\begin{array}{l}\text { WIPP } \\
\text { Brine } \\
\end{array}$ & $\begin{array}{l}\mathrm{CaCl}_{2} \\
\text { Solution }\end{array}$ & $\begin{array}{c}\mathrm{NaCl} \\
\text { Solution } \\
\end{array}$ & $\begin{array}{r}\mathrm{NaHCO}_{3} \\
\text { Solution } \\
\end{array}$ & $\begin{array}{l}\text { De ion ized } \\
\text { Water }\end{array}$ \\
\hline 1 & 1 & $4 E-5$ & $6 E-5$ & $7 E-5$ & $1 E-4$ & $8 E-5$ \\
\hline 2 & 2 & $8 E-6$ & $1 E-5$ & $8 E-6$ & $3 E-5$ & $2 E-5$ \\
\hline 3 & 3 & $3 E-5$ & $2 E-5$ & $9 E-6$ & $4 E-5$ & $1 E-5$ \\
\hline 4 & 4 & $2 E-5$ & $1 E-5$ & $2 E-6$ & $1 E-5$ & $6 E-6$ \\
\hline 5 & 11 & $3 E-6$ & $3 E-6$ & $3 E-6$ & $2 E-6$ & $5 E-6$ \\
\hline 7 & 25 & $2 E-6$ & $2 E-6$ & $2 E-6$ & $4 E-7$ & $4 E-6$ \\
\hline 12 & 60 & $2 E-7$ & $1 E-6$ & $2 E-6$ & $3 E-7$ & $4 E-6$ \\
\hline 15 & 154 & $8 E-7$ & $6 E-6$ & $5 E-6$ & $5 E-7$ & $9 \mathrm{E}-6$ \\
\hline 19 & 277 & (a) & (a) & (a) & (a) & (a) \\
\hline 23 & 404 & (a) & (a) & (a) & (a) & (a) \\
\hline 25 & 467 & $6 E-7$ & $3 E-8$ & $2 E-6$ & $1 E-6$ & $4 E-6$ \\
\hline
\end{tabular}

(a) analysis not availble at time of reporting. 
IAEA LEACH RATE BASED ON $125 \mathrm{Sb}\left(\mathrm{g} / \mathrm{cm}^{2}\right.$-day)

FOR 28,000 MWd/MTU SPENT FUEL AT $25^{\circ} \mathrm{C}$

\begin{tabular}{|c|c|c|c|c|c|c|}
\hline Series & $\begin{array}{c}\text { Cumulative } \\
\text { Days }\end{array}$ & $\begin{array}{l}\text { WIPP } \\
\text { Brine } \\
\end{array}$ & $\begin{array}{l}\mathrm{CaCl}_{2} \\
\text { Solution }\end{array}$ & $\begin{array}{c}\mathrm{NaCl} \\
\text { Solution } \\
\end{array}$ & $\begin{array}{r}\mathrm{NaHCO}_{3} \\
\text { Solution } \\
\end{array}$ & $\begin{array}{c}\text { Deionized } \\
\text { Water } \\
\end{array}$ \\
\hline 1 & 1 & $1.1 E-4$ & $1.4 \mathrm{E}-4$ & $1.4 \mathrm{E}-4$ & $4.6 E-4$ & $2.0 E-4$ \\
\hline 2 & 2 & $4.6 E-5$ & $2.4 E-5$ & $5.1 E-5$ & $6.9 E-5$ & $7.9 E-5$ \\
\hline 3 & 3 & $2.9 E-5$ & $2.3 E-5$ & $3.0 E-5$ & $4.5 E-5$ & $3.6 E-5$ \\
\hline 4 & 4 & $1.6 E-5$ & $9.8 E-6$ & $1.3 E-5$ & $2.3 E-5$ & $2.3 E-5$ \\
\hline 5 & 11 & $6.2 E-6$ & $1.7 \mathrm{E}-5$ & $1.4 E-5$ & $1.1 E-5$ & $3.4 E-5$ \\
\hline 7 & 25 & $5.0 \mathrm{E}-6$ & $1.3 E-5$ & $1.5 \mathrm{E}-5$ & $2.9 E-6$ & $1.4 \mathrm{E}-5$ \\
\hline 12 & 60 & $3.0 E-6$ & $2.1 E-6$ & $5.4 E-6$ & $5.6 E-6$ & $1.1 E-5$ \\
\hline 15 & 154 & $2.9 E-6$ & $1.6 E-6$ & $1.9 E-6$ & $2.7 E-6$ & $1.8 E-5$ \\
\hline 19 & 277 & $8.1 E-6$ & $1.0 E-5$ & $1.8 E-6$ & $3.7 E-6$ & $1.7 E-5$ \\
\hline 23 & 404 & $8.2 E-6$ & $1.8 E-6$ & $6.7 \mathrm{E}-7$ & 7.7 E-6 & $1.0 E-5$ \\
\hline 25 & 467 & $3.8 E-6$ & $7.6 \mathrm{E}-8$ & $3.5 \mathrm{E}-6$ & $7.0 E-6$ & $1.3 E-5$ \\
\hline
\end{tabular}

IAEA LEACH RATE BASED ON ${ }^{144} \mathrm{Ce}\left(\mathrm{g} / \mathrm{cm}^{2}\right.$-day)

FOR 28,000 MWd/MTU SPENT FUEL AT $25^{\circ} \mathrm{C}$

\begin{tabular}{|c|c|c|c|c|c|c|}
\hline Series & $\begin{array}{c}\text { Cumulative } \\
\text { Days } \\
\end{array}$ & $\begin{array}{l}\text { WIPP } \\
\text { Brine } \\
\end{array}$ & $\begin{array}{l}\mathrm{CaCl}_{2} \\
\text { Solution } \\
\end{array}$ & $\begin{array}{c}\mathrm{NaCl} \\
\text { Solution } \\
\end{array}$ & $\begin{array}{c}\mathrm{NaHCO}_{3} \\
\text { Solution } \\
\end{array}$ & $\begin{array}{c}\text { Deionized } \\
\text { Water }\end{array}$ \\
\hline 1 & 1 & $1.5 E-4$ & $8.8 E-5$ & $1.3 \mathrm{E}-4$ & $6.3 \mathrm{E}-5$ & $1.5 \mathrm{E}-4$ \\
\hline 2 & 2 & 8.2 E-6 & $1.7 E-5$ & $9.6 E-6$ & $2.6 E-5$ & $4.6 E-5$ \\
\hline 3 & 3 & $2.9 E-5$ & $7.1 \mathrm{E}-6$ & $1.4 \mathrm{E}-5$ & $2.6 \mathrm{E}-5$ & $2.3 E-5$ \\
\hline 4 & 4 & $1.1 E-5$ & $4.9 E-6$ & $1.1 E-5$ & $2.0 E-5$ & $1.8 E-5$ \\
\hline 5 & 11 & $7.7 E-6$ & $2.5 E-5$ & $2.2 E-5$ & $1.7 \mathrm{E}-6$ & $5.0 E-5$ \\
\hline 7 & 25 & $2.6 \mathrm{E}-6$ & $1.6 E-5$ & $1.5 \mathrm{E}-5$ & $1.5 \mathrm{E}-6$ & $1.2 \mathrm{E}-5$ \\
\hline 12 & 60 & $3.2 E-6$ & $4.4 E-6$ & $1.2 \mathrm{E}-5$ & $1.7 \mathrm{E}-6$ & $1.5 E-5$ \\
\hline 15 & 154 & $5.1 \mathrm{E}-6$ & $2.1 E-6$ & $1.2 \mathrm{E}-6$ & $1.2 \mathrm{E}-7$ & $1.7 E-5$ \\
\hline 19 & 277 & $5.6 \mathrm{E}-7$ & $1.0 E-5$ & $2.4 E-6$ & $6.0 \mathrm{E}-7$ & $1.5 E-5$ \\
\hline 23 & 404 & $7.0 \mathrm{E}-7$ & $1.8 \mathrm{E}-6$ & $8.4 \mathrm{E}-7$ & $9.7 \mathrm{E}-7$ & $1.2 E-5$ \\
\hline 25 & 467 & $9.4 E-7$ & $1.1 \mathrm{E}-7$ & $3.5 E-6$ & $1.0 \mathrm{E}-7$ & $1.2 \mathrm{E}-5$ \\
\hline
\end{tabular}




\begin{tabular}{|c|c|c|c|c|c|c|}
\hline Series & $\begin{array}{c}\text { Cumulat ive } \\
\text { Days } \\
\end{array}$ & $\begin{array}{l}\text { WIPP } \\
\text { Brine }\end{array}$ & $\begin{array}{l}\mathrm{CaCl}_{2} \\
\text { Solution } \\
\end{array}$ & $\begin{array}{c}\mathrm{NaCl} \\
\text { Solution } \\
\end{array}$ & $\begin{array}{l}\mathrm{NaHCO}_{3} \\
\text { Solution } \\
\end{array}$ & $\begin{array}{c}\text { Deionized } \\
\text { Water }\end{array}$ \\
\hline 1 & 1 & $1.5 E-4$ & $1.5 E-4$ & $1.4 E-4$ & $1.7 \mathrm{E}-4$ & $2.3 E-4$ \\
\hline 2 & 2 & $2.1 E-5$ & $2.0 E-5$ & $2.2 E-5$ & $3.9 E-5$ & $5.4 E-5$ \\
\hline 3 & 3 & $2.5 E-5$ & $1.9 E-5$ & $2.7 E-5$ & $3.4 E-5$ & $3.1 E-5$ \\
\hline 4 & 4 & $1.2 \mathrm{E}-6$ & $1.4 E-5$ & $1.5 E-5$ & $3.4 E-5$ & $1.4 E-5$ \\
\hline 5 & 11 & $6.8 E-6$ & $2.3 E-5$ & $1.7 E-5$ & $2.4 E-6$ & $3.1 E-5$ \\
\hline 7 & 25 & $6.3 E-6$ & $1.4 E-5$ & $1.9 E-5$ & $1.1 E-6$ & $8.1 E-6$ \\
\hline 12 & 60 & $3.5 E-6$ & $2.4 E-6$ & $6.8 E-6$ & $1.4 E-6$ & $8.1 E-6$ \\
\hline 15 & 154 & $5.2 E-6$ & $3.6 \mathrm{E}-6$ & $3.9 E-6$ & $5.7 \mathrm{E}-7$ & $1.4 E-5$ \\
\hline 19 & 277 & $2.8 E-6$ & $3.4 E-6$ & $7.6 \mathrm{E}-7$ & $3.5 E-7$ & $5.8 E-6$ \\
\hline 23 & 404 & $2.8 E-6$ & $7.2 \mathrm{E}-7$ & $3.6 \mathrm{E}-7$ & $7.1 \mathrm{E}-7$ & $3.9 E-6$ \\
\hline 25 & 467 & $3.1 E-6$ & $1.4 E-7$ & $3.3 E-6$ & $8.2 \mathrm{E}-7$ & $9.6 E-6$ \\
\hline
\end{tabular}

IAEA LEACH RATE BASED ON $137 \mathrm{Cs}\left(\mathrm{g} / \mathrm{cm}^{2}\right.$-day) FOR $28,000 \mathrm{MWd} / \mathrm{MTU}$ SPENT FUEL AT $25^{\circ} \mathrm{C}$

\begin{tabular}{|c|c|c|c|c|c|c|}
\hline Series & $\begin{array}{c}\text { Cumulat ive } \\
\text { Days } \\
\end{array}$ & $\begin{array}{l}\text { WIPP } \\
\text { Brine } \\
\end{array}$ & $\begin{array}{l}\mathrm{CaCl}_{2} \\
\text { Solution }\end{array}$ & $\begin{array}{c}\mathrm{NaCl} \\
\text { Solution }\end{array}$ & $\begin{array}{c}\mathrm{NaHCO}_{3} \\
\text { Solution } \\
\text { Solution }\end{array}$ & $\begin{array}{c}\text { Deionized } \\
\text { Water }\end{array}$ \\
\hline 1 & 1 & $1.2 \mathrm{E}-3$ & $1.2 \mathrm{E}-3$ & $1.1 \mathrm{E}-3$ & $1.4 E-3$ & $3.8 E-3$ \\
\hline 2 & 2 & $5.9 E-5$ & $8.1 E-5$ & $6.8 E-5$ & $1.2 \mathrm{E}-4$ & $1.3 E-4$ \\
\hline 3 & 3 & $5.1 \mathrm{E}-5$ & $3.8 E-5$ & $4.8 E-5$ & 8.9 E-5 & 7.5 E-5 \\
\hline 4 & 4 & $2.0 \mathrm{E}-5$ & $1.6 E-5$ & $2.4 E-5$ & $6.4 E-5$ & $4.8 E-5$ \\
\hline 5 & 11 & $1.2 \mathrm{E}-5$ & $3.2 E-5$ & $2.5 E-5$ & $4.2 E-5$ & $6.6 \mathrm{E}-5$ \\
\hline 7 & 25 & $8.9 \mathrm{E}-6$ & $2.1 E-5$ & $2.4 E-5$ & $1.9 E-5$ & $2.8 E-5$ \\
\hline 12 & 60 & $6.4 \mathrm{E}-6$ & $6.7 \mathrm{E}-6$ & $1.3 E-5$ & $1.1 \mathrm{E}-5$ & $1.6 \mathrm{E}-5$ \\
\hline 15 & 154 & $3.8 \mathrm{E}-6$ & $7.5 \mathrm{E}-6$ & $8.8 \mathrm{E}-6$ & $3.7 E-6$ & $2.1 E-5$ \\
\hline 19 & 277 & $7.0 \mathrm{E}-6$ & $8.8 E-6$ & $4.8 \mathrm{E}-6$ & $2.3 E-6$ & $1.6 E-5$ \\
\hline 23 & 404 & $7.1 \mathrm{E}-6$ & $2.0 E-6$ & 3.1 E-6 & $3.8 E-6$ & $6.8 E-6$ \\
\hline 25 & 467 & $3.8 E-6$ & $8.9 E-7$ & $6.1 \mathrm{E}-6$ & $3.3 E-6$ & $1.2 E-5$ \\
\hline
\end{tabular}


IAEA LEACH RATE BASED ON $154 \mathrm{Eu}\left(\mathrm{g} / \mathrm{cm}^{2}\right.$-day) FOR 28,000 MWd/MTU SPENT FUEL AT $25^{\circ} \mathrm{C}$

\begin{tabular}{|c|c|c|c|c|c|c|}
\hline$\underline{\text { Series }}$ & $\begin{array}{c}\text { Cumulative } \\
\text { Days } \\
\end{array}$ & $\begin{array}{l}\text { WIPP } \\
\text { Brine } \\
\end{array}$ & $\begin{array}{l}\mathrm{CaCl}_{2} \\
\text { Solution }\end{array}$ & $\begin{array}{c}\mathrm{NaCl} \\
\text { Solution }\end{array}$ & 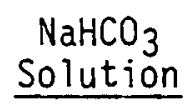 & $\begin{array}{c}\text { Deionized } \\
\text { Water }\end{array}$ \\
\hline 1 & 1 & $1.4 \mathrm{E}-4$ & $1.3 E-4$ & $1.6 \mathrm{E}-4$ & $8.7 E-5$ & $2.1 \mathrm{E}-4$ \\
\hline 2 & 2 & $1.0 E-5$ & $2.0 E-5$ & $1.2 E-5$ & $3.6 E-5$ & $5.1 E-5$ \\
\hline 3 & 3 & $3.1 E-5$ & $1.0 E-5$ & $1.8 E-5$ & $3.4 E-5$ & $2.5 E-5$ \\
\hline 4 & 4 & $2.9 E-5$ & $7.8 E-6$ & $1.5 E-5$ & $2.9 E-5$ & $1.8 E-5$ \\
\hline 5 & 11 & 8.0 E-6 & $2.8 E-5$ & $2.2 \mathrm{E}-5$ & $2.6 \mathrm{E}-6$ & $4.9 E-5$ \\
\hline 7 & 25 & $3.0 \mathrm{E}-6$ & $2.1 \mathrm{E}-5$ & $2.1 E-5$ & $2.3 E-6$ & $1.6 \mathrm{E}-5$ \\
\hline 12 & 60 & $3.1 E-6$ & $5.7 E-6$ & $1.1 \mathrm{E}-5$ & $1.8 \mathrm{E}-6$ & $1.0 \mathrm{E}-5$ \\
\hline 15 & 154 & $3.1 E-6$ & $4.9 E-6$ & $5.3 E-6$ & $2.0 \mathrm{E}-7$ & $2.1 E-5$ \\
\hline 19 & 277 & $9.5 E-7$ & $1.1 \mathrm{E}-5$ & $2.5 E-6$ & $5.1 E-7$ & $2.0 E-5$ \\
\hline 23 & 404 & $1.9 E-6$ & $7.0 \mathrm{E}-7$ & $9.0 \mathrm{E}-7$ & $8.2 E-7$ & $1.2 E-5$ \\
\hline 25 & 467 & $2.2 E-6$ & $1.2 \mathrm{E}-7$ & $6.9 E-6$ & $9.9 E-6$ & $1.5 E-5$ \\
\hline
\end{tabular}

IAEA LEACH RATE BASED ON 239 $\mathrm{pu}+240 \mathrm{pu}\left(\mathrm{g} / \mathrm{cm}^{2}-\right.$ day $)$ FOR 28,000 MWd/MTU SPENT FUEL AT $25^{\circ} \mathrm{C}$

\begin{tabular}{|c|c|c|c|c|c|c|}
\hline Series & $\begin{array}{c}\text { Cumul at ive } \\
\text { Days } \\
\end{array}$ & $\begin{array}{l}\text { WIPP } \\
\text { Brine } \\
\end{array}$ & $\begin{array}{l}\mathrm{CaCl}_{2} \\
\text { Solution }\end{array}$ & $\begin{array}{c}\mathrm{NaCl} \\
\text { Solution }\end{array}$ & $\begin{array}{c}\mathrm{NaHCO}_{3} \\
\text { Solution } \\
\end{array}$ & $\begin{array}{c}\text { Deionized } \\
\text { Water }\end{array}$ \\
\hline 1 & 1 & $2.4 E-5$ & $3.0 E-5$ & $2.9 E-5$ & $7.1 E-5$ & $5.9 E-5$ \\
\hline 2 & 2 & $9.2 E-6$ & $6.5 E-6$ & $1.4 E-5$ & $2.4 E-5$ & $2.1 E-5$ \\
\hline 3 & 3 & $9.7 E-6$ & $1.1 E-5$ & $1.6 E-5$ & $2.4 E-5$ & $2.4 E-5$ \\
\hline 4 & 4 & $5.9 E-6$ & 7.1 E-6 & 6.1 E-6 & $9.7 E-6$ & $1.2 \mathrm{E}-5$ \\
\hline 5 & 11 & $2.3 E-6$ & $9.7 E-6$ & $9.2 E-6$ & $2.1 E-6$ & $2.6 E-5$ \\
\hline 7 & 25 & $9.2 E-7$ & 9.1 E-6 & $9.5 E-6$ & $1.4 E-6$ & $2.3 E-5$ \\
\hline 12 & 60 & $1.4 E-6$ & $4.7 E-6$ & 7.4 E-6 & $9.5 E-7$ & $1.5 E-5$ \\
\hline 15 & 154 & $2.4 E-6$ & $3.1 E-6$ & $2.7 E-6$ & $1.2 \mathrm{E}-7$ & $1.7 \mathrm{E}-5$ \\
\hline 19 & 277 & $5.8 E-6$ & $6.7 E-6$ & $1.1 E-6$ & $4.8 E-7$ & $1.3 E-5$ \\
\hline 23 & 404 & $5.3 E-6$ & $2.1 E-6$ & $7.5 \mathrm{E}-7$ & $6.0 \mathrm{E}-7$ & $8.1 \mathrm{E}-6$ \\
\hline 25 & 467 & $3.7 \mathrm{E}-6$ & $1.6 \mathrm{E}-7$ & $3.0 E-6$ & $2.1 E-7$ & $1.1 \mathrm{E}-5$ \\
\hline
\end{tabular}




\begin{tabular}{|c|c|c|c|c|c|c|}
\hline Series & $\begin{array}{c}\text { Cumu lat ive } \\
\text { Days } \\
\end{array}$ & $\begin{array}{l}\text { WIPP } \\
\text { Brine }\end{array}$ & $\begin{array}{l}\mathrm{CaCl}_{2} \\
\text { Solution } \\
\end{array}$ & $\begin{array}{c}\mathrm{NaCl} \\
\text { Solution }\end{array}$ & $\begin{array}{l}\mathrm{NaHCO}_{3} \\
\text { Solution } \\
\end{array}$ & $\begin{array}{c}\text { Deionized } \\
\text { Water }\end{array}$ \\
\hline 1 & 1 & $3.1 \mathrm{E}-5$ & $2.8 \mathrm{E}-5$ & $3.5 E-5$ & $8.7 E-5$ & $3.7 E-5$ \\
\hline 2 & 2 & $5.1 E-6$ & $1.2 E-5$ & $4.8 E-6$ & $1.4 E-5$ & $1.5 \mathrm{E}-5$ \\
\hline 3 & 3 & $2.0 E-5$ & $4.2 E-6$ & $6.0 \mathrm{E}-6$ & $1.2 E-5$ & $4.8 E-6$ \\
\hline 4 & 4 & $8.9 \mathrm{E}-6$ & $2.3 \mathrm{E}-6$ & $4.3 E-6$ & $7.6 \mathrm{E}-6$ & $3.0 \mathrm{E}-6$ \\
\hline 5 & 11 & $7.3 \mathrm{E}-6$ & $4.4 E-6$ & $3.8 E-6$ & $1.8 \mathrm{E}-6$ & $2.1 E-6$ \\
\hline 7 & 25 & $5.0 \mathrm{E}-6$ & $1.9 \mathrm{E}-6$ & $2.1 E-6$ & $1.1 E-6$ & $2.5 E-6$ \\
\hline 12 & 60 & 5.0 E-6 & $4.8 E-7$ & $8.9 \mathrm{E}-7$ & $5.5 \mathrm{E}-7$ & $1.5 \mathrm{E}-6$ \\
\hline 15 & 154 & $2.0 E-6$ & $2.8 \mathrm{E}-7$ & $5.0 \mathrm{E}-7$ & $2.1 E-7$ & $2.0 E-6$ \\
\hline 19 & 277 & $7.9 E-7$ & $6.0 \mathrm{E}-6$ & $3.3 \mathrm{E}-7$ & $3.2 \mathrm{E}-7$ & $1.5 \mathrm{E}-6$ \\
\hline 23 & 404 & $5.4 \mathrm{E}-7$ & $1.2 \mathrm{E}-6$ & $1.7 \mathrm{E}-7$ & $5.1 \mathrm{E}-7$ & $1.1 \mathrm{E}-6$ \\
\hline 25 & 467 & $3.8 \mathrm{E}-7$ & $3.7 \mathrm{E}-7$ & $5.1 \mathrm{E}-7$ & $1.3 \mathrm{E}-7$ & $1.8 E-6$ \\
\hline
\end{tabular}





\section{DISTRIBUTION}

No. of

Copies

OFFSITE

\author{
A. A. Churm \\ DOE Chicago Patent Division \\ 9800 South Cass Avenue \\ Argonne, IL 60439
}

27 DOE Technical Information Center

B. Adams

Corning Glass Works

Technical Staffs Division

Corning, NY 14830

Allied Chemical Corporation

(File Copy)

550 2nd Street

Idaho Falls, ID 83401

J. M. Batch

Battelle Memorial Institute

505 King Avenue

Columbus, $\mathrm{OH} 43201$

Battelle Memorial Institute

Office of Nuclear Waste Isolation

Attn: Beverly Rawles

505 King Avenue

Columbus, $\mathrm{OH} 43201$

J. R. Berreth

Allied Chemical Corporation

550 2nd Street

Idaho Falls, ID 83401

R. E. Blanco

Union Carbide Corporation (ORNL)

Chemical Technology Division

P.0. Bpx Y

Oak Ridge, TN 37830

J. 0. Blomeke

Union Carbide Corporation (ORNL)

P.0. Box $Y$

Oak Ridge, TN 37830
No. of

Copies

Brookhaven National Laboratory

Reference Section

Information Division

Upton, NY 11973

R. A. Buckham

Allied-General Nuclear Service P.0. Box 847

Barnwe 11, SC 29812

Wayne Carbiener

Office of Nuclear Waste Isolation

505 King Avenue

Columbus, $\mathrm{OH} 43201$

T. C. Chee

DOE Office of Nuclear Waste Management

Washington DC 20545

R. B. Chitwood

DOE Division of Nuclear Power Development

Washington DC 20545

5 D. Coles

Lawrence Livermore Laboratory

P.0. Box 808

Livermore, CA 94550

P. Colombc

Department of Applied Science

Brookhaven National Laboratory

Upton, NY 11973

C. R. Cooley

DOE Office of Nuclear Waste Management

Washington DC 20545

J. L. Crandall

E. I. duPont DeNemours and Company

Savannah River Laboratory

Aiken, SC 29801 
No. of

Copies

R. E. Cunn ingham

Deputy Director for Fuels and Materials

Nuclear Regulatory Commission

Silver Springs, MD 20910

H. Diamond

Argonne National Laboratory

9700 South Cass Avenue

Argonne, IL 60439

J. P. Duckworth

Plant Manager

Nuclear Fuel Services, Inc.

P.0. Box 124

West Valley, NY 14171

J. 0 . Duguid

Office of Nuclear Waste Isolation

505 King Avenue

Columbus, $\mathrm{OH} 43201$

Environmental Protection Agency

Technology Assessment Division (AW-559)

Office of Radiation Programs

Washington DC 20460

Keith Flynn

Argonne National Laboratory

9700 South Cass Avenue

Argonne, IL 60439

A. Friedman

Argonne National Laboratory

9700 South Cass Avenue

Argonne, IL 60439

R. G. Garvin

E. I. duPont DeNemours and Company

Savannah River Laboratory

Aiken, SC 29801
No. of

Copies

H. W. Godbee

Union Carbide Corporation (ORNL)

Chemical Technology Division

P.0. Box $Y$

Oak Ridge, TN 37830

E. S. Goldberg

DOE Savannah River Operations Office

P.0. Box A

Aiken, SC 29801

Mark Harwe 11

P.0. Box 667

Cannon Beach, OR 97110

C. A. Heath

DOE Office of Nuclear Waste

Management

Washington DC 20545

R. E. Heineman

Office of Nuclear Waste

Isolation

$505 \mathrm{King}$ Avenue

Columbus, $\mathrm{OH} 43201$

L. L. Hench

Department of Materials Science and Engineering

University of Florida

Gainsville, FL 32611

H. Henning

Electric Power Research Institute

3412 Hillview Avnue

P.0. Box 10412

Palo Alto, CA 94301

Peter Hoffman

Office of Nuclear Waste Isolation

$505 \mathrm{King}$ Avenue

Columbus, $\mathrm{OH} 43201$ 
No. of

Copies

J. L. Jardine

Argonne National Laboratory

9700 South Cass Avenue

Argonne, IL 60439

J. K. Johnstone

Sandia Laboratories

Albuquerque, NM 87107

J. A. Kelley

E. I. dePont DeNemours and Company

Savannah River Laboratory

Aiken, SC 29801

C. J. Kershner

Mons anto Research Corporation Mound Laboratory

P.0. Box 32

Miamisburg, $\mathrm{OH} 45342$

J. F. Kircher

Office of Nuclear Waste Isolation

Battelle Memorial Institute

$505 \mathrm{King}$ Avenue

Columbus, $\mathrm{OH} 43201$

D. A. Knecht

Allied Chemical Corporation

550 2nd Street

Idaho Falls, ID 83401

E. H. Kobish

Solid State Division

Oak Ridge National Laboratory

Oak Ridge, TN 37830

D. Lam

Argonne National Laboratory

9700 South Cass Avenue

Argonne, IL 60439

Paul W. Levy

Brookhaven National Laboratory Upton, NY 11973
No. of

Copies

S. E. Logan

Los Alamos Technical

Associates, Inc.

P.0. Box 410

Los Alamos, NM 87544

Los Alamos Scientific Laboratory (DOE)

P.0. Box 1663

Los Alamos, NM 87544

J. B. Martin

United States Nuclear Regulatory Commission

Washington DC 20555

W. C. McClain

RE/SPEC Inc.

P.0. Box 725

Rapid City, SD 57701

M. D. McCormack

E.G. \& G. Idaho, Inc.

P.0. Box 1625

Idaho Falls, ID 83401

Sheldon Meyers

DOE Office of Nuclear Waste Management

Washington DC 20545

Don Moak

Office of Nuclear Waste

Isolation

$505 \mathrm{King}$ Avenue

Columbus, $\mathrm{OH} 43201$

M. A. Molecke Sandia Laboratories

Albuquerque, MN 87107

W. E. Mott

DOE Division of Environmental Control Technology

Washington DC 20545 
No. of

Copies

J. Neff, Program Manager Department of Energy Columbus Program Office 505 King Avenue

Columbus, $\mathrm{OH} 43201$

R. M. Neilson, Jr. Department of Applied Science Brookhaven National Laboratory Upton, NY 11973

Ed Norr is

Los Alamos Scientific Laboratory

CNC-DO Mailstop 760

Los Alamos, NM 87545

2 Oak Ridge National Laboratory (DOE)

Central Research Library

Document Reference Library

P.0. Box $X$

Oak Ridge, TN 37830

G. Oertel

DOE Office of Nuclear Waste Management

Washington DC 20545

\section{Al Ogle}

Los Alamos Scientific Laboratory

CNC-CO Mailstop 760

Los Alamos, NM 87545

A. F. Perge

DOE Office of Nuclear Waste Management

Washington DC 20545

M. S. Plodinec

E. I. duPont DeNemours and Company

Savannah river Laboratory

Aiken, SC 29801
No. of

Copies

\author{
John Pomeroy \\ Technical Secretary \\ National Academy of Sciences \\ Committee of Radioactive Waste \\ Management \\ National Research Council \\ 2101 Constitution Avenue \\ Washington DC 20418 \\ R. G. Post \\ College of Engineering \\ University of Arizona \\ Tucson, AZ 85721 \\ Professor Guna Salvaduray \\ Materials Engineering \\ San Jose State University \\ San Jose, CA 95192 \\ L. Ramspott \\ Lawrence Livermore Laboratory \\ P.0. Box 808 \\ Livermore, CA 94550 \\ D. M. Rohrer \\ United States Nuclear Regulatory \\ Commission \\ Washington DC 20555 \\ R. G. Romatowski \\ DOE Office of Nuclear Waste \\ Management \\ Washington DC 20545 \\ B. Scheetz \\ 210 Materials Research \\ Laboratory \\ Pennsyivania State University \\ University Park, PA 16802 \\ T. Scott \\ Ames Laboratory \\ Iowa State University \\ Ames, IA 50011
}


No. of

Copies

W. C. Seymour

E.G. \& G. Idaho, Inc.

P.0. Box 1625

Idaho Falls, ID 83401

M. J. Ste ind ler

Argonne National Laboratory

9700 South Cass Avenue

Argonne, IL 60439

D. B. Stewart

U.S. Department of Interior

959 National Center

Geological Survey

Reston, Virginia 22092

J. Tewhey

Lawrence Livermore Laboratory

P.0. Box 808

Livermore, CA 94550

John Van Cleve

DOE Oak Ridge Operation Office

P.0. Box X

Oak Ridge, TN 37830

E. Vejovoda, Director

Chemical Operations

Rockwell International

Rocky Flats Plant

P.0. Box 464

Golden, CO 80401

D. L. Vieth

DOE Office of Nuclear Waste Management

Washington DC 20545

J. W. Voss

Office of Nuclear Waste

Management

Battelle Memorial Institute

$505 \mathrm{King}$ Avenue

Columbus, $\mathrm{OH} 43201$
No. of

Copies

R. D. Walton

DOE Office of Nuclear Waste Management

Washington DC 20545

W. Weart

Sandia Laboratories

Albuquerque, NM 87107

H. Weed

Lawrence Livermore Laboratory

P.0. Box 808

Livermore, CA 94550

W. White

210 Materials Research Laboratory

Pennsylvania State University

University Park, PA 16802

J. B. Whitsett

DOE Idaho Operations Office

550 2nd Street

Idaho Falls, ID 83401

A. Williams

Allied-General Nuclear Service

P.0. Box 847

Barnwe 11, SC 29812

FOREIGN

Dr. P. G. Alfredson

Chief, Chemical Technology Division

Australian Atomic Energy Commission

Research Establishment

Lucas Heights, New South Wales, 2232

Rene Amavis

EURATOM

Health Physics Division

29, Rue Aldringer

Luxembourg

BELGIUM 
No. of

Copies

R. Bonniaud

Center de Marcoule

B.P. 170

30200 Baguo ls-Sur-Ceze

FRANCE

Bundesministerium fur Forschung und Technologie

Stressemannstrasse 2

5300 Bonn

WEST GERMANY

Center for Atomic Energy

Documentation (ZAED)

Attn: Dr. Mrs. Bell

P.0. Box 3640

7500 Kar lsruhe

WEST GERMANY

D. W. Clell and

United Kingdom Atomic Energy Authority

Risley

ENGLAND

F. Gera

CHEN

CSN Cassaccia L.I.S.

C.P. 24,00 00100

Rome

ITALY

K. B. Harvey

Atomic Energy of Canada, Ltd.

W.N.R.E. Pinawa, Manitoba

ROE 1 LO

CANADA

Ake Hultgren

Studsvik Energiteknik $A B$

S-611 82 Nykoping

SWEDEN

International Atomic Energy Agency

Kartner Ring 11

P.0. Box 590

A-1011, Vienna

AUSTRIA
No. of

Copies

K. D. B. Johnson

Atomic Energy Research

Establishment,

Harwe 11, Didcot,

Berks

ENGLAND

H. Krause

Kernforschungszentrum Karlsruhe GmbH (KfK)

Postfach 3640

D7500 Kar lsruhe

WEST GERMANY

F. Laude

Centre de Marcoule

B.P. 170

30200 Baguo ls-Sur-Ceze

FRANCE

Hans W. Levi

Hahn-Meitner Institut

1 Berlin 39

Glien ickerstr. 100

WEST GERMANY

Library

Studsvik Energiteknik $A B$

S-611 01Nykoping

SWEDEN

Dr. Werner Lutze

Hahn-Me itner

Institut fur Kernforschung

Berlin, GmbH

Glienicker Strasse

100, B-1000

Berlin, 39

GERMANY

J. A. C. Marples

Atomic Energy REsearch

Establishment

Harwe 11, Didcot,

Berks

ENGLAND 
No. of

Copies

E. R. Merz

Institut fur Chemische

Technologie

Kernforschungsanloge Julich GmbH

D517 Julich

Postfach 365

Federal Republic

WEST GERMANY

Ton is Papp

Swed ish Nuclear Supply Co.

SKBF/KBS

Box 5864

S-102 48 Stockholm

SWEDEN

N. S. Aunder Rajan

Bhabha Atomic Research Centre Goverment of India

Hall No. 5

Trombay

Bombay 85

INDIA

P. J. Regnaut

Centre d'Etudes Nucleaires de

Fontenay-aux Roses

Boite Postale 6

92 - Fontenay-aux Roses

FRANCE

A. Rice

Department of Ocean Engineering

University of Newcastle upon

Tyne

Newcast le upon Tyne, NE I 7 RU

ENGLAND

Dr. Piero Risoluti,

AGIP NUCLEARE

C/O COMB Casaccia

C.p. 2400

Rome

ITALY
No. of

Copies

Rolf Sjoblom

Studsvik Energiteknik $A B$

S-611 82 Nykoping

SWEDEN

C. Sombret

Centre de Marcoule

B.P. 170

30200 Baguols-Sur-Ceze

FRANCE

G. G. Strathdee

Atomic Energy of Canada, Ltd.

W.N.R.E. Pinawa, Manitoba

ROE 1 LO

CANADA

S. Tashiro

Japan Atomic Energy Research Institute

Environmental Safety research Laboratory

1-1-13, Shibashi

Minatopku, Tokyo

JAPAN

M. Tomlinson

Director of Chemistry and Materials Science division Atomic Energy of Canada Ltd. Whiteshel1 Nuclear Research Establishment

Pinawa, Manitoba

CANADA

T. T. Vandergraaf

Atomic Energy of Canada, Ltd. W.N.R.E. Pinawa, Manitoba ROE $1 L 0$

CANADA 
No. of

Copies

ONSITE

5 DOE Richland Operations Office

P. A. Craig

H. E. Ransom

J. J. Schreiber

M. W. Shupe

M. J. Zamorski

10 Rockwell Hanford Operations

J. Babad

M. Bensky

R. A. Deju

R. J. Gimera

J. D. Kaser

M. J. Kupfer

W. W. Schultz

M. J. Smith

D. D. Wodrich

File Copy

Exxon Nuclear Company

S. J. Beard

Joint Center for Graduate Study

J. Cooper

2 United Nuclear Industries, Inc.

T. E. Dabrowski

A. E. Engler

4 Westinghouse Hanford Company
A. G. Blasewitz
D. A. Cant ley
R. L. Fish
A. C. Leaf

109 Pacific Northwest Laboratory

S. M. Barnes

G. L. Benson
No. of

Copies

W. J. Bjork lund

H. T. Blair

W. F. Bonner

D. J. Bradley (10)

A. Brandstetter

R. A. Brouns

J. B. Brown, Jr.

J. L. Buelt

R. L. Bunnell

L. A. Chick

T. D. Chikalla

D. B. Cear lock

M. O. Clon inger

G. W. Dawson

W. J. Deutsch

R. D. Dierks

F. H. Dove

J. W. Finnigan

W. J. Gray

M. S. Hanson

F. T. Hara

C. 0. Harvey (2)

M. H. Henry

O. F. Hill

L. K. Holton

B. Howes

J. H. Jarrett

Y. B. Katayama

W. S. Kelly

R. S. Kemper

D. E. Knowiton

K. M. Krupka

M. R. Kreiter

W. L. Kuhn

D. E. Larson

R. P. Marshall

J. L. McElroy

G. L. McVay (10)

G. B. Mellinger

J. E. Mende 1

R. D. Nelson

W. R. Nelson

R. E. Nightingale

D. E. Olesen

C. R. Palmer

R. D. Peters

L. R. Pederson 
No. of

Copies
A. M. Platt
D. Rai
J. F. Relyea
F. P. Roberts
W. A. Ross
J. M. Rusin
J. L. Ryan
R. J. Serne
J. W. Shade
D. H. Siemens
D. J. Silviera
S. C. Slate
R. G. Strickert
J. L. Swanson

No. of

Copies
M. T. Thomas
R. T. Treat
R. P. Turcotte
H. H. Van Tuyl
J. W. Wald
W. E. Weber
R. A. Walter
R. Wang
J. H. Westsik, Jr.
L. D. Williams
Technical Information (5)
Publishing Coordination $\mathrm{SH} / \mathrm{B}(2)$
Water and Land Resource
Library (10) 
